\title{
Resilient Social Actors in the Transition from the Late Bronze to the Early Iron Age on Cyprus
}

\author{
Nathan Meyer $^{1}$ D $\cdot$ A. Bernard Knapp ${ }^{2}$ D
}

Accepted: 24 November 2021 / Published online: 29 December 2021

(c) The Author(s) 2021

\begin{abstract}
Our understanding of the earliest Iron Age on Cyprus has long remained somewhat obscure. This is the result of both a relative lack of material evidence and the fact that scholarly attention has focused more on the preceding Late Bronze Age and on the subsequent Cypro-Archaic period. As more, and more varied, data have accumulated, there have been calls for a more theoretically informed approach to considering the social changes involved, and even for prehistorians to extend their work into the Cypriot Iron Age. As a response to this, the present study considers a broad range of material and documentary evidence, attempts to reconstruct the political economy, and offers an interpretative framework based on social understandings of Complex Adaptive Systems theory. Using this approach, the authors conclude that, while the enduring realities of Cyprus-its geography, copper resources and long tradition of agropastoralism-continued to shape Cypriot culture, the Iron Age is not simply a continuation of its Bronze Age sociopolitical forms. We argue instead that the earliest Iron Age involved social actors negotiating new politico-economic agendas in response to changing conditions in the Iron Age eastern Mediterranean.
\end{abstract}

Keywords Cyprus $\cdot$ Iron Age $\cdot$ Social actors $\cdot$ Complex adaptive systems $\cdot$ Political economy

Nathan Meyer

nathanxmeyer@berkeley.edu

A. Bernard Knapp

bernard.knapp@glasgow.ac.uk

1 Department of Anthropology, University of California, Berkeley, CA 94720, USA

2 Archaeology, Department of Humanities, University of Glasgow, Glasgow G12 8QQ,

Scotland, UK 


\section{Introduction}

Over the past three decades, the concept of 'collapse' has stimulated a great deal of world archaeological research on prehistoric as well as historic societies (e.g. McAnany \& Yoffee, 2010; Middleton, 2017; Schwartz \& Nichols, 2006; Tainter, 1988; Yoffee \& Cowgill, 1988). Not least amongst this body of work is a series of volumes treating the decline of several polities of the Late Bronze Age (LBA) Aegean and eastern Mediterranean, observed to have taken place within a halfcentury either side of 1200 ВС (e.g. Bachhuber \& Roberts, 2009; Fischer \& Bürge, 2017; Galil et al., 2013; Middleton, 2020). Notwithstanding earlier, occasional evidence for iron working in the wider ancient Near East, it is the now quite welldocumented increase in extractive metallurgy (mining, smelting) on Cyprus and in the Levant during the twelfth century BC (see Erb-Satullo, 2019 for summary) that supports the conventional nomenclature change from 'bronze' to 'iron' in the region. However, the long-standing emphasis on the notion of a widespread 'collapse' in the thirteenth-twelfth centuries $\mathrm{BC}$ eastern Mediterranean has perhaps over-influenced the way in which we think about the LBA versus the Early Iron Age (EIA). The result is a binary form of 'before' and 'after' thinking that is, of course, not representative of human experience within a continuum of change.

In what can be seen as a reasonable response to such binary thinking, the communis opinio on Cyprus has tended to focus primarily on continuity between these two periods. As detailed in this study, a primary support for this argument comes in the form of the uneven pace and scale of change across the island at the end of the thirteenth and into the twelfth century BC. Absent an island-wide, abrupt collapse, continuity is posited instead. Our argument here is that this notion of continuity runs the risks of denying the EIA its historical specificity and of missing its unique character. Beyond the island's enduring geological and geographical realities, there is a substantial discontinuity between these two periods that merits close attention to issues of collapse and regeneration. Although the Iron Age is - in many respects - an outgrowth of cultural traditions from the Bronze Age, we regard these periods and the cultures that represent them as distinct: the Bronze Age may inform the Iron Age, but it does not define it. The political and economic regime(s) of the Bronze Age disappeared and-as elsewhere in the Aegean and eastern Mediterranean-Cypriot society evolved in other ways to engage with new, Iron Age, social and politico-economic realities.

As a polity (or polities) that seems to have weathered at least some of the destabilising conditions that affected the surrounding regions, Cyprus offers an opportunity to reconsider the transformations that occurred at the end of the LBA, and to consider various environmental conditions, social institutions and geopolitical strategies that characterised the island's resilience, ultimately leading to the emergence of new, Iron Age regimes. Building on a recent paper (Knapp \& Meyer, 2020) that treated a limited data set to explore the post-collapse situation on Cyprus, here we broaden our consideration of the available data and confront more directly the prevailing paradigm of Early Iron Age polities on the island. We question whether the so-called 'city-kingdoms' that became well established on 
the island by the onset of the Cypro-Archaic period (c. $750 \mathrm{BC}$ ) were the result of social, political and economic transformations that took place during the eleventh century $\mathrm{BC}$, or whether, by contrast, they represented new polity formations that emerged during the ninth-eighth centuries BC. Whereas Iacovou (2013, p. 37) has argued that the process leading to the formation of the Cypro-Archaic polities must have begun no later than the twelfth century $\mathrm{BC}$, the details of that process remain vague and contentious, particularly in the absence of settlement data and the over-reliance on evidence from cemeteries, sanctuaries, inscriptions and foundation myths (e.g. Rupp, 1988; Vanschoonwinkel \& Karageorghis, 1994; Papantoniou, 2012a; Fourrier, 2013; Janes, 2013).

Iacovou (2013) suggested that Cypriot polities had an inherent frailty, in part the result of environmental constraints but also partly due to a reliance on the-at times-industrial level of outward-bound trade in copper metal; using ancient Cyprus's abundant forests for fuel, metallic copper was extracted from the massive sulphide ore deposits within the Pillow Lavas that encircle the central Troodos mountain range. As we are in accord with Iacovou's suggestion, one of our main aims here is to assess the nature of Cyprus's Early Iron Age polities by analysing the evidence for the political economy, namely that portion of the overall economic structure that lies beyond subsistence needs or the household. As Kristiansen and Earle (2015, p. 238) recently noted, an approach focusing on the political economy examines links between economic, political and institutional structures in the attempt to identify different social groups both horizontally (links to economic networks) and vertically (levels of social complexity).

Our focus therefore falls upon issues such as large-scale agricultural production and surplus storage, industrial-scale mineral resource extraction and craft production, and the volume and types of exchange, local and more distant. To pursue these lines of evidence, we examine a broad array of information, including settlement data, mortuary remains, pottery production and metalworking, raw metal sourcing and availability, and the role of rural sanctuaries-all in a preliminary and exploratory manner, intended to encourage further dialogue and research. Although we believe that the political economy of Cyprus diminished in scale and importance substantially during the transition from the LBA to the EIA and only began to expand again toward the end of the Cypro-Geometric period (c. 750 BC) (see also Petit, 2019), we acknowledge that this general picture is complicated by the island's regional histories and will only become clearer through further study and publication of existing data and the emergence of relevant new data.

We present our argument within a framework drawn from the study of Complex Adaptive Systems and networks, hereafter CAS (Bernabeu Aubán et al., 2012; Buckley, 1968; Lansing, 2003). A social understanding of CAS theory is typified by several features salient to the study of human societies, most notably the prominence given to networked social actors as agents of punctuated, adaptive change. Below, we present CAS in more detail, and show how we use its features to help interpret changes within Cypriot society during the transition from the Late Bronze to the Early Iron Age. 


\section{Background}

In this section, we consider briefly the prevailing interpretations for the rise of the Iron Age kingdoms of Cyprus, and the extent to which they developed from Bronze Age antecedents or emerged anew some two to three centuries after the Bronze Age came to an end.

\section{Early Iron Age Cyprus: Current Views}

In a broader study of Early Iron Age Greece and Anatolia, Muhly (2003, p. 26) argued that the lack of settlement evidence for both Cyprus and Crete during the eleventh century $\mathrm{BC}$ was a 'major weakness' in all previous research on the period. Along with a range of other factors (e.g. over-reliance on mortuary evidence or foundation myths), the paucity of settlement evidence on Cyprus during the centuries between c. 1100-800 BC has led to two opposing positions about the nature of the island's Early Iron Age polities and the date at which they emerged (detailed argument with references below):

(1) a 'consolidation' around $750 \mathrm{BC}$ of earlier political formations that originated in the twelfth century BC; and

(2) the emergence of entirely new sociopolitical formations from the ninth-eighth centuries BC onward.

Conceptualisations of Cyprus's eleventh-tenth centuries BC polities are manifold, and include 'chiefdoms' (Rupp, 1998, pp. 215-216; Petit, 2019, pp. 69-75), 'petty kingdoms' (Peltenburg \& Iacovou, 2012, p. 351), 'city-kingdoms' (Papantoniou, 2016, pp. 76-77), 'territorial kingdoms' (Fourrier, 2013, p. 104), or even 'city-states' (Iacovou, 2013, p. 36). Such polities, it is argued, were ruled by (w)anaktes ('kings') (Snodgrass, 1988, pp. 12, 19) or 'predator heroes' (Catling, 1994, pp. 137-138), 'big men' (Petit, 2001, p. 63) or basileis ('rulers') (Iacovou, 2006), even 'warrior princes' (Muhly, 2003, pp. 24-25, 31). For the most part (but cf. Iacovou, 2014), these attempts to define the nature of Cyprus's Early Iron Age polities fail to take on crucial questions about the makeup of the political economy and the full gamut of social actors within it, the spatial dimension of power, or the kind of territory-agricultural land, metallurgical deposits, forests, coastal resources-that any polity would have.

Let us now look in more detail at the two prevailing schools of thought on the emergence of Cyprus's Early Iron Age polities.

\section{The ‘Cypro-Centric’ View}

Foremost amongst attempts to expound on the economic and political organisation of Cyprus's Early Iron Age polities is a self-ascribed 'Cypro-centric' viewpoint. This view envisions a general continuity between the 'heterarchical' sociopolitical 
and economic structures of the island's LBA polities and those of the early Iron Age 'city-kingdoms' (e.g. Iacovou, 2007a, p. 461, 2007b, p. 16; Satraki, 2012, pp. 262-263; Georgiou, 2015, pp. 130-131, 2017, pp. 208-211; Papantoniou, 2016, pp. 89-90; Georgiou \& Iakovou, 2020, pp. 1133-1134). In a recently published paper, Papantoniou and Kryiakou (2018, p. 542) express this viewpoint succinctly:

The Late Cypriot polities of the second millennium BC represent the first phase of a system that resisted the development of a central state. The Iron Age polities, which endured to the end of the fourth century $\mathrm{BC}$, may be viewed as the culmination of these earlier indigenous political institutions.

In the above quote, the word 'system' is used in a general sense, but is made more explicit in Iacovou's (2018, p. 21) recent entry on the debate:

No matter how one wishes to define these authorities-principalities, kingdoms, chiefdoms, city-states, or simply institutionalized merchant networksmy contention is that there was never a time when Cyprus was without any regional managing structures.

These 'regional managing structures' are regarded as both persistent and geographically/geologically predetermined but also as idiosyncratic, with regionally specific trajectories (for example, three distinct administrative languages - Greek, Phoenician, 'Eteo-Cypriot'). As such, these interpretations would require the 'citykingdoms' to be uniformly a distinctly Cypriot form of regionalism but in this specific instance also the end result of a long process initiated at the close of the Late Cypriot (LC) period (even if they were only 'consolidated' some 300 to 500 years later: for the chronology, see Table 1).

Iacovou (2018, p. 9) has recently argued that in order to understand this Cypriot distinctiveness, one must read through (and 'feel') —in the original Greekthe writings of eighteenth and nineteenth century Cypriot authors; she suggests

Table 1 Late Bronze-Early Iron Age Cyprus chronology (prepared by A. Bernard Knapp)

\begin{tabular}{lll}
\hline Periods & & Dates BC \\
\hline $\begin{array}{l}\text { Late Bronze Age (Protohistoric Bronze Age-ProBA) } \\
\text { (Middle Cypriot III-Late Cypriot IIIA) }\end{array}$ & \\
Middle Cypriot III-Late Cypriot I & ProBA 1 & $1750 / 1700-1450$ \\
Late Cypriot IIA-IIC early & ProBA 2 & $1450-1340$ \\
Late Cypriot IIC late-IIIA & ProBA 3 & $1340-1125 / 1100$ \\
Early Iron Age & & \\
Late Cypriot IIIB & & $1125 / 1100-1050$ BC \\
Cypro-Geometric I & & $1050-950$ BC \\
Cypro-Geometric II & & $950-900$ BC \\
Cypro-Geometric III & & $900-750$ BC \\
(Iron Age City States) & & \\
Cypro-Archaic I & & $750-600$ BC \\
Cypro-Archaic II & & $600-475$ BC \\
\hline
\end{tabular}


that failing to do so puts one at risk of falling into a colonialist point of view. While we can agree that Cyprus is indeed a conspicuously unique island, we do not believe this necessarily results in a form of unbroken continuity and we dispute the assertion that the competing argument of discontinuity 'has been negated' (Georgiou \& Iacovou, 2020, p. 1134). Nonetheless, we remain in accord with some of the postulates of the Cypro-centric view, as demonstrated elsewhere in this study.

\section{The 'Secondary State' View}

Prominent counterviews maintain that the politico-economic organisation of LBA Cyprus-whether centralised or heterarchical-disappeared after the twelfth century BC (LC IIIA), and that hierarchically organised, regional polities only reappeared on the island during or after the late ninth century BC. Petit (2001, pp. 55-65, 2015, 2019), for example, has long argued that the paucity of settlement evidence and the lack of other relevant material or documentary support for the Cypro-Geometric period (c. 1050-750 BC) mean that archaeological markers of a 'state' only become evident during the latter half of the ninth century BC. In a series of articles, Rupp (1987, 1989, 1998) put forward a somewhat later date-during the mid-late eighth century $\mathrm{BC}$ - for the emergence of the first 'secondary states' on Early Iron Age Cyprus; he viewed these developments as an economic and political response to the expansionist economic policies of the Phoenicians - as the trading arm of the Neo-Assyrian state-who had established a colony at Kition during the ninth century вС (Rupp, 1987, pp. 153-155). Smith (2008, pp. 278-279) suggested that the power shifts evident in the material and documentary records of Early Iron Age Cyprus reflect a reaction to Neo-Assyrian imperialism and the presence of Phoenician kings at Kition who sought to expand their presence and influence on Cyprus from the ninth century BC onward.

More recently, Körner (2016, 29-30) has used the concept of centre and periphery to characterise Cyprus's relationship with the Neo-Assyrian state, positing as well that Cypriot polities of the eighth century BC may have owed tribute to a mainland intermediary state. Cannavò (2018, pp. 243-251), despite assuming an eleventh century BC foundation for the Cypro-Archaic kingdoms, followed by an 'obscure and poorly documented phase', likewise makes a convincing argument that, beginning in the later Cypro-Geometric phase of CG III, economic relations with Phoenicia played a central role in the 'transformation of Early Iron Age Cypriot polities into territorial kingdoms' (Cannavò, 2018, p. 250). Likewise, Kearns (2015, 2017, 2019), although focusing on the effects of increasingly wetter conditions on rural opportunities (including copper exploitation), suggests that the later CG III is the critical period of expansion.

In order to evaluate these two viewpoints, we first establish the LBA setting on Cyprus as the context in which any 'continuities' with the Early Iron Age must be identified. 


\section{The Late Cypriot Context}

Two recent volumes (Knapp, 2008, pp. 131-297, 2013, pp. 348-476) discuss at length the archaeological and textual evidence for Late Cypriot Bronze Age (LC) society that we summarise here. As Cyprus entered the LBA, the island was already primed for what would become a period of increasing social complexity driven by external demand for its most valuable export: copper. Against the backdrop of a durable, if not always richly productive, agropastoralism (Andreou, 2016, 2019), the people of Cyprus had a long-standing practice of exploiting their native copper ores for both local use and off-island export. The LBA, however, was particularly marked by an intensification of copper production and distribution. As externally oriented, urbanised settlements appeared along the coasts, others in a settlement hierarchy dotted the interior of the island, including sites for resource extraction and agricultural production (Knapp, 1997, pp. 48-63).

Off-island exchange is amply attested in contemporary written records, which include cuneiform documents from Ugarit (Syria), Egypt (Tell el-Amarna) and Hittite Anatolia, but also oblique mentions in Linear B documents from Crete and the Greek mainland (for the texts, see Knapp, 1996; for detailed interpretation, see Knapp, 2008, pp. 307-341). External trade is also fully evident in the steadily increasing amounts of imported exotica found in multiple, often mortuary contexts (Keswani, 2004, 136-139). In return, Cyprus exported raw materials such as copper and timber and, as the LC II period progressed, increasing amounts of pottery. Despite what one might expect from a copper-producing polity, the archaeological record for the earlier LC period is notable for a lack of finished bronze artefacts of any kind, and evidence for production of finished bronzes (as well as other crafts) does not emerge as a notable component of the LC economy until the thirteenth century BC (Papasavvas, 2012).

None of these changes took place without individual people acting to preserve or attain something of value; such actions took place within a broader network of interrelationships and in fact would have resulted in adaptations to the social matrix. As archaeological evidence demonstrates, Cyprus underwent profound social change during the LBA: increasing urbanisation; new forms of monumental and visually imposing architecture; decisive changes in burial types and mortuary practices within urban centres; social signalling using the visual language of Levantine and Egyptian elites (see Knapp, 2008, pp. 134-201). Non-elites are less directly visible but all these changes must have impacted broadly across society. The intensification of copper production alone would have driven many changes, not least the formation of a labouring class, perhaps enslaved to some degree, necessary for the mining and smelting of copper ore. Growing specialisation in production activities generally, increasing rates and eventually industrialisation of pottery manufacture, and the mere fact that more people were engaged in the 'wealth' versus the 'staple' economy (Keswani, 1993) drove additional changes. At the same time, however, agropastoralism remained fundamental to rural society, and the material and social practices of rural communities continued to provide a deep, ongoing source of tradition.

As already noted, a key component of the Cypro-centric view is that Cyprus 'resisted' a central state in favour of 'regional management'. Against such claims 
regarding, for example, the lack of royal symbolism (Georgiou \& Iacovou, 2020, p. 1137), our view is that the material and documentary evidence of LBA Cyprus (at least from the mid fourteenth to late thirteenth century BC) is indicative of centralised control by an internationally recognised king (e.g. Knapp, 2013, pp. 432-447; see also Peltenburg, 1996, pp. 27-37; Webb, 1999, pp. 305-308). This formidable LBA polity had the sociopolitical and ideological means to organise the production and distribution of copper on the broad scale attested for the LBA. At the very least, we may envision a loosely centralised polity characterised by intensive intraisland interaction on various scales (Andreou, 2015, pp. 397-412). As the period proceeded, there was scope for the growth of power and wealth outside the formal channels of the administrative state. This long-term trend-resulting in both hierarchical and heterarchical political and social power-coincided with a set of stressors both within Cypriot society and without (a turbulent geopolitical context). As we argue below, in combination these factors ultimately led to the demise of centralised authority around the end of LC IIC, c. 1200 BC.

With this synopsis of the LC period in place, we now consider 'stressors' on LC society, in order to contextualise the 'collapse' and to identify some possible factors involved in change and transformation.

\section{Stressors on Late Cypriot Society}

The reality of significant disturbances to societies in the eastern Mediterranean around $1200 \mathrm{BC}$ is relevant to any understanding of the Early Iron Age on Cyprus. The stressors discussed in this section are, broadly speaking, external to LC society but in some cases correlated with others that are internal. Together, they represent drivers for innovation and cultural change.

\section{‘Crisis' C. 1200 BC}

Space here does not allow a recapitulation of scholarly views on the so-called 'sea peoples' (the traditional capitalisation of this term perhaps suggests something rather too distinct); our focus falls instead on the general 'crisis'. Thus, it must suffice to say that, to the extent that any 'sea peoples' existed, such social formations, however they were actually constituted ethnically or otherwise, were not merely aggressors but victims of the same disintegration of interconnected cultures in the LBA eastern Mediterranean (Voskos \& Knapp, 2008, p. 659).

Some reconstructions of the crisis focus on the erosion of state-sponsored trade and its replacement by a new form of mercantile trade (e.g. Sherratt 1998, 2016a). Others argue for frontier pressure (e.g. in Anatolia-Glatz \& Matthews, 2005) or a form of systems collapse wherein the palace-centred economy simply exhausted its potential (various papers in Middleton, 2020). Still others cite evidence of drought (e.g. Kaniewski \& Van Campo, 2017; Kaniewski et al., 2013), but linking this evidence to specific cases of agricultural disruption demands much more precise dating (Knapp \& Manning, 2016; see further below). 
Whereas many of the politically dominant states of the LBA eastern Mediterranean suffered dissolution or loss of territory, local histories have proved more difficult to disentangle. Moreover, the ambiguity and varied quality of a century-long series of excavations and subsequent reporting (or not) of archaeological fieldwork means that the multiple, diverse destructions and abandonments in the eastern Mediterranean around $1200 \mathrm{BC}$ do not lend themselves directly to any coherent or agreedupon interpretation (Knapp \& Manning, 2016, pp. 126-134; Millek, 2019). While we cannot-with any precision-align dates of potential environmental challenges or disentangle the collapse of regional powers into an interdependent series of sitespecific examples, the general disruptions to socioeconomic networks and political regimes at this time cannot be denied. There is little chance that Cyprus would not have been affected, whether directly exposed to the troubles or indirectly impacted by any large-scale shift in the political economy and the resulting fall-off in trade, particularly (but perhaps not only) the trade in copper.

\section{An Unstable Political System?}

We mentioned above the emergence on Cyprus during the LC period of either hierarchical or heterarchical (or both) forms of political and social power. Perhaps the most convincing argument supporting the notion of independent polities on LBA Cyprus is the spacing of coastal emporia, which seems to reflect independent local histories rather than centralised control (Keswani, 1993, p. 75). For example, Kalavasos Ayios Dhimitrios and the Maroni complex of sites, which lay no more than $7 \mathrm{~km}$ from one another, both developed as urban centres and then were abandoned abruptly (Manning et al., 2014; South-Todd, 2002) (for all site locations, see Fig. 1). Having examined the spatial organisation of these two sites, Andreou (2015, pp. 392-393) concluded that regional particularities were fully evident at both. In our view, such evidence points to an experimental phase in LC urbanisation, fuelled by the accumulation of wealth and power outside the formal administrative channels of the island-wide polity. Conditions of relative stability facilitated such opportunism and the attendant increase in networked communications, factors that, as we argue below, would also have sown the seeds for potential instability.

Against any presumption of multiple, politically independent emporia stands the issue of the bulk export of copper and the socioeconomic organisation needed to provide such export. Gale and Stos-Gale (2012) argued, controversially, that all bulk copper produced on Cyprus after 1400 BC for trading purposes came from the Apliki mine in northwestern Cyprus (cf. Knapp, 2013, pp. 413-416). They also argued that finished metal products contained copper from both the Apliki mine and other ore sources around the Troodos, suggesting one process for extracting and processing copper (trade purposes) and another for manufacturing metal goods (Gale \& StosGale, 2012, p. 71). Whatever its merits, this reconstruction supports the concept of a single political entity overseeing the external trade in Cypriot copper: a single, dominant, external-facing polity managed the bulk trade in copper by controlling the extraction process, primary and secondary smelting, and transport while at the same time contending with the pressures of increasing entrepreneurialism (both within 


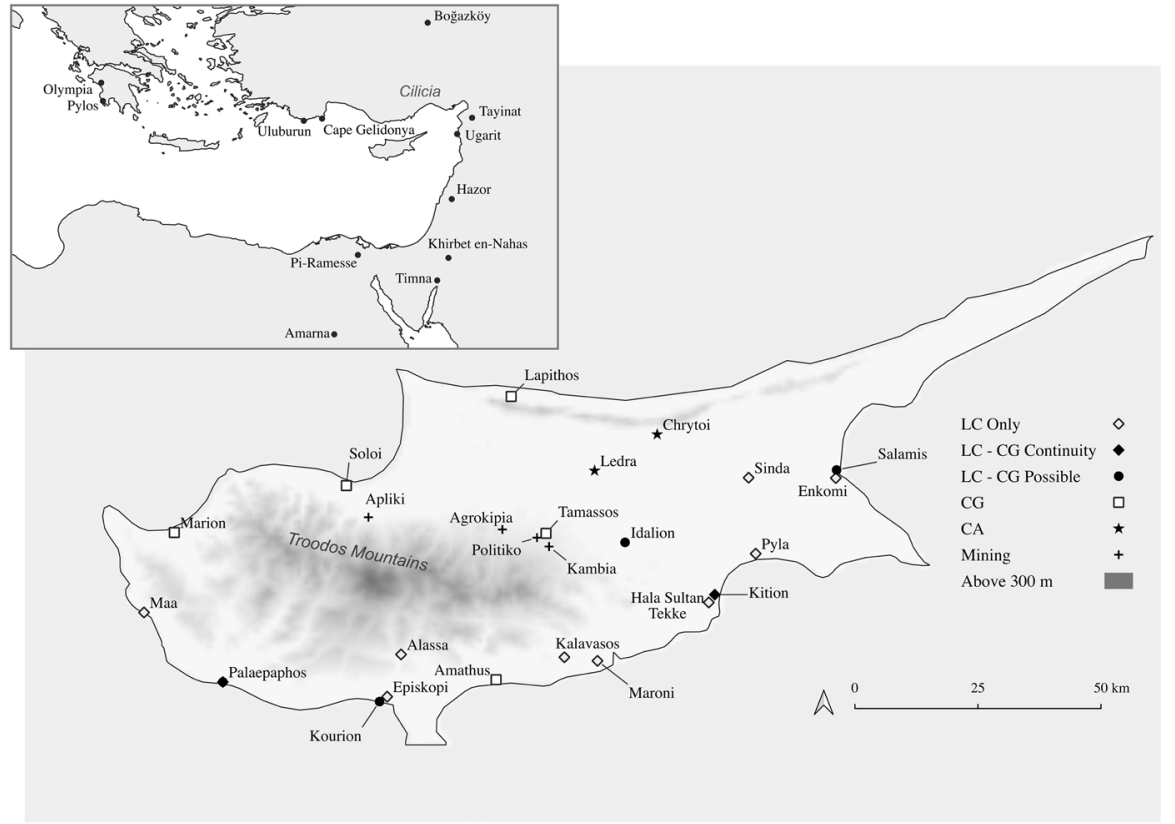

Fig. 1 Map showing all sites mentioned in the text (prepared by Nathan Meyer)

and beyond the island) and a shifting international scene. The picture that emerges is one where continued decentralising tendencies worked against a single island-wide polity and opened the way to less stable conditions on the island overall. This situation clearly acted as a stressor on LC society.

\section{Settlement Disruption in the Late Cypriot Period}

Several of the main coastal or near-coastal towns of LBA Cyprus were abandoned or destroyed over a period of time between the late thirteenth century and the midtwelfth century вС (Knapp, 1997, pp. 54-55, table 2; Georgiou, 2011, pp. 114-117, 2015; Iacovou, 2013, pp. 25-26). With respect to the island's political economy, it is worth stressing that some sites with significant industrial or agricultural storage capacity-e.g. Kalavasos Ayios Dhimitrios, Maroni Vournes, Alassa Paleotavernawere abandoned (Georgiou, 2011, p. 116, 2015, pp. 131-135) (for sites, see Fig. 1).

Trying to identify a single pattern for all sites involved in the LC IIC-IIIA disruptions seems futile. Such is the complexity of the timeline of changes on Cyprus that Iacovou (2005a, p. 129) considered any narrative of widespread destruction as an 'overpowering stigma' not borne out by the data. Georgiou (2011) likewise has argued that the settlement history of LBA Cyprus tells a mixed story. Abandonments at Kalavasos Ayios Dhimitrios and Maroni Vournes by the close of the thirteenth century $\mathrm{BC}$ appear to have been accompanied by the removal of portable goods, giving the appearance of a 'peaceful abandonment' (Georgiou, 2015, p. 131). Whether 
the inhabitants of these sites had time to gather up their belongings or whether such goods were subsequently looted is more than we can confidently discern. Nonetheless, such abandonments stand in contrast to contemporaneous signs of growth at sites such as Kition and Palaepaphos, where new, monumental building projects were undertaken (Georgiou, 2015, p. 133, 2017). Indeed, Peltenburg and Iacovou (2012, p. 355) argued that these new monumental buildings represent the Iron Age's first hierarchical states, formed around an increasingly centralised authority supported by an ideology associating cult and copper production (but cf. Smith, 2009, pp. 77-78; Petit, 2019, pp. 39-40).

When looking specifically at abandonments, some occur without any apparent preceding destructions (e.g. at Ayios Dhimitrios and Maroni, perhaps also at Alassa Paleotaverna and Episkopi Bamboula-Georgiou, 2015, pp. 132-133); others, however, occur after multiple destructions, as at Enkomi and Hala Sultan Tekke Vyzakia (Georgiou, 2015, pp. 131-132; Fischer \& Bürge, 2018, pp. 612-613). While one could argue that reuse of an existing settlement was simply opportunistic, we would argue that location was important enough to justify rebuilding some settlements repeatedly before their final abandonment; such an interpretation indicates a still extant but weakening geopolitical environment and attendant politico-economic realities.

These urban centres did not exist in a vacuum and would have had close relationships with interior sites focused on 'staple' production (Keswani, 1993, p. 78). The disruptions evident in LC IIC-IIIA settlements are thus not only about coastal destructions and abandonments but equally about their ramifying impacts and settlement interrelationships. As Iacovou (2012, p. 217) noted: 'Entire Late Cypriot communities had been uprooted and family groups were dispersed, moving in different directions and looking to relocate elsewhere'. All such disruptions collectively represent a major stressor on Late Cypriot society.

\section{Colonisation or Expanding Communications?}

The discovery of Mycenaean or 'Aegean-style' pottery on Cyprus has long been associated with the notion of an Aegean colonisation of Cyprus (Voskos \& Knapp, 2008). The apparent pattern, as established at Sinda and Enkomi (Dikaios, 1967; Furumark, 1965), was that of a destruction layer followed shortly by reoccupation or new habitation with evidence of pottery typed as (Aegean) Late Helladic IIIC:1b. Such conclusions were strengthened by Karageorghis's excavations at Maa Palaeokastro and Pyla Kokkinokremos, where more 'Aegean-style' pottery was found alongside Cypriot pottery (Karageorghis \& Demas, 1984, 1988). Contrary to the colonisation narrative posited for these sites, however, an intensive review of the material from Maa and Pyla found nothing to distinguish them from other contemporary Cypriot sites (Georgiou, 2012).

Susan Sherratt, an early critic of the colonisation narrative, argued that the influx of 'Aegean-style' pottery was the result of mercantile activity: first imports and then, once supply had dwindled, locally-made import substitution on an industrial scale (Sherratt, 1992, 1994b; see also Steel, 1998, p. 287). Despite the increasing amount 
of such pottery during the twelfth century BC, it comprises only a small fraction of the total volume of ceramics and appears mainly in funerary contexts, mostly as closed containers and drinking sets, as noted by Steel (1998, pp. 290-292). Steel also noted that most Late Helladic pottery uncovered in settlement contexts came from 'ritual or ceremonial activity associated with feasting and some sort of libation rite' (Steel, 2004, p. 75). 'Aegean-style' pottery thus played specific, well-integrated social roles alongside local pottery. Rather than being evidence for the presence of colonists, it represents first an intermixing and then a fusion of local and foreign ceramic traditions (see also Georgiou, 2015, pp. 135-137, 2017, pp. 221-223).

Standing the colonisation narrative on its head, Cook (1988) argued that many of the influences seen in LC III material culture derived from the Levant, and that some pottery motifs previously thought of as Aegean in origin may actually have moved in the opposite direction (Cook, 1988, p. 15; see also Sherratt, 1994b, p. 42). Similarly, looking at architecture and various materials recovered in 'cultic settings' in the eastern Mediterranean, Albers (1996) found no clear indication of Aegean influences in Cyprus or along the Levantine coast and in fact saw more Levantine than Aegean impact on Cyprus.

We agree with Iacovou's (2018, pp. 17-18) view that narratives (conscious or unconscious) focusing on colonialism, whether Aegean in the Late Cypriot (LC) or Phoenician in the Cypro-Geometric (CG), need careful scrutiny. In fact, we would argue that the focus on an 'Aegean colonisation' has blinded scholars to a more subtle but no less consequential fact. As the LC period came to a close, the movement of people, goods and ideas - from both east and west, into and out of Cyprus-was increasing. Such intensifying levels of interconnection represent not just highly localised moments of opportunity, but in aggregate a significant force for disruption and stress on society (as well as significant impetus for change supported by new traditions).

\section{The Value of Copper and The Scarcity of Tin}

Here we focus on the economics and viability of the trade in metals. It is worth noting at the outset that while Cyprus was (and is) rich in sulphidic-copper ores and has a significantly smaller amount of polymetallic ore with notable arsenic levels, the island has no tin. Indeed, it has been argued that control over the import and disposition of tin on the island would have played a role in the formation of local elites (Kassianidou, 2003); we look further at disruptions to the tin trade below. Concerning the value of bulk copper, there are indications that copper-producing regions other than Cyprus were also active in the eastern Mediterranean during the thirteenth century BC. For example, the thirteenth century BC workshops of PiRamesse in New Kingdom Egypt provide evidence for the use of ores consistent with production not only from Cypriot sources, but also from two other sources, the Arabah and possibly Oman (Rademakers et al., 2017). Although the scale of production is uncertain, increasingly it seems apparent that copper sources at Timna in the Negev (Yagel et al., 2016) and in the Sinai Peninsula (Abdel-Motelib et al., 2012) could have been exploited during the LBA. Thus, it would seem that copper 
was not in short supply. Relative metal values vary from place to place and period to period, yet attempts to calculate LBA copper's value in the eastern Mediterranean have yielded different but essentially similar interpretations of a relatively low value vis-à-vis gold or silver (e.g. Monroe, 2010 uses Hittite and Ugaritic cuneiform evidence to arrive at 1:4:800; Papasavvas, 2012, pp. 124-125 and more expansively in Papasavvas, 2021, pp. 131-140, and fig. 10:34, uses New Kingdom Egyptian and cuneiform texts from Ugarit to arrive at 1:2:200 or 1:4:800).

A potentially significant, fourth 'source' of copper evident in the Egyptian PiRamesse workshops was recycled metal. Sherratt (1994a, p. 64) and Artzy (2003, p. 18) have maintained that-from the thirteenth into the twelfth centuries BCthere was an overall increase in the amount of bronze in circulation. In turn, Sherratt (1999, pp. 175-177, 2016b, p. 611) suggested that demand for bronze products across an ever-widening network drove increased trading relations as well as increased recycling.

But was the recycling of bronzes driven by demand, or by a fall in supply, namely of tin? Sherratt $(1998,2003$, p. 41) saw recycling not as a sign of shortage but rather the end result of the increasing commodification of bronze, the rise of commercial ventures (outside elite-controlled channels), an ever-increasing demand for finished products as well as the emergence of new, 'sub-elites' (e.g. itinerant merchants). This need not have been an either/or situation: it may be that the supply of copper was ample, that finished bronze artefacts or bronze alloys were increasingly commodified and that the supply of tin was a key local variable. Recycling thus may have more specific meaning if we consider the availability of tin and the role it played in the political economy of LC II-III Cyprus.

Assuming that large quantities of low-value copper were in circulation during what has been called 'the climax of bulk maritime trade' at the end of the LBA (Sherratt \& Sherratt, 1991, p. 372), one reaction appears to have been a trend toward producing finished bronze artefacts. An increasing focus on producing such objects, or even a shift in emphasis from exporting copper to manufacturing bronzes, makes economic sense. It likewise indicates a significant change in the political economy. Tin was of vital importance to the Cypriot bronzeworking industry, an industry that by the thirteenth century BC had become a 'hallmark of Cypriot art' (Papasavvas, 2012 , p. 120). A relative scarcity or disrupted availability of tin would have had a meaningful impact on Cyprus's political economy. The discovery of metallic tin ingots off Israel's Carmel coast (Galili et al., 1986, p. 25, 2013, pp. 6-8) and the recovery from the Uluburun shipwreck of approximately one tonne of tin in various ingot types (Pulak, 2000, pp.150-151, 2009), demonstrates that during the LBA, at least, tin was traded as a metal.

Since it is widely acknowledged that the copper oxhide ingots (Fig. 2) found on the Uluburun ship were of Cypriot origin, we must consider briefly the possible tin sources used on LBA Cyprus. Even if Cornwall cannot now be ruled out as a potential source of tin for the LBA eastern Mediterranean (Berger et al., 2019), central Asian sources still must be taken into account (Stöllner et al., 2011). Kassianidou (2003, p. 116) noted the significance of Levantine ports for the eastern tin trade but suggested they may have been adversely affected by the disruption in trade routes to the east that followed upon the LBA 'collapse' (see also Zaccagnini, 1990, p. 
Fig. 2 Copper oxhide ingot said to come from Asia Minor. The Metropolitan Museum of Art Rogers Fund, 1911 (11.140.7). Image courtesy of the Metropolitan Museum of Art

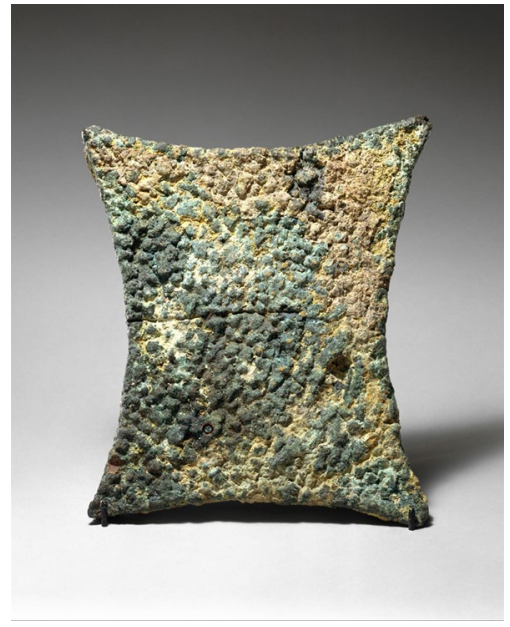

498; Artzy, 2003, pp. 18, 20). Bell (2006, pp. 109-110) likewise concluded that the destruction of Ugarit would have had an especially negative impact on the availability of tin traded into the Mediterranean from the east. Disruptions in the tin supply chain and the destruction of Levantine entrepôts would have dealt decisive (even if intermittent) blows to bronzeworking on Cyprus during the twelfth century BC (similarly Waldbaum, 1999, p. 39).

Having analysed metal objects from four locations in the eastern Mediterranean with tin concentrations ranging between $<1 \%$ and $16.3 \%$, Pickles and Peltenburg (1998, p. 86) argued against a general shortage of tin in the region during the twelfth century BC. The same study (Pickles \& Peltenburg, 1998, p. 73, table 2), however, shows wide variability between sites. LC IIIA bronzes from burials at Palaepaphos also revealed high levels of tin but some also showed relatively high levels of arsenic (Pickles, 1988, pp. 21-22; Charalambous, 2016, pp. 570-571). We read these points not so much as a ringing endorsement of an abundant tin supply but instead as a demonstration of the location and time-specific availability of tin. Indeed, elsewhere on Cyprus there are signs of variability in such availability. Charalambous (2016, p. 572), for example, notes that more the half of the LBA Cypriot copper alloy artefacts analysed from Pyla Kokkinokremos had less than 5\% tin; the only high-tin samples came from broken artefacts (suggesting recycling).

The tin shortage we suggest also seems evident in the remains of the two most prominent shipwrecks of the LBA-those found at Uluburun (dated c. $1300 \mathrm{BC}$ ) and Cape Gelidonya (c. 1200 BC) off the southern coast of Anatolia. The Uluburun wreck carried one tonne of metallic tin in the form of oxhide and bun ingots and ten tonnes of copper (Pulak, 2009, p. 193). At this time, as attested by cuneiform texts from Ugarit, tin had the same value as copper (Monroe, 2010, p. 23). By contrast, the Cape Gelidonya wreck contained some $800 \mathrm{~kg}$ of copper ingots but only $16 \mathrm{~kg}$ of suspected tin residue, one bronze slab ingot with $5 \%$ tin and a single bronze bun ingot with 7.08\% tin (Bass et al., 1967, pp. 78, 82). Return visits to the Gelidonya wreck have only identified 'very tentatively' the presence of further 'tin concretions' 
(Hirschfeld \& Bass, 2013, p. 102). The contrasting availability of tin as represented in these two shipwrecks separated by about a hundred years suggests that, by the end of the LBA, metallic tin was less readily or less reliably available.

In sum, with respect to the availability of metals at the LBA-EIA transition, Cyprus clearly was a supplier of bulk copper but not the only one, and the value of copper itself was compromised by an abundant supply of both copper metal and recycled bronzes. Furthermore, the full value of Cypriot copper was only fully realised as an ingredient in tin bronze, which necessitated a steady supply of tin. Any disruption to the tin trade, even in very localised settings and for periods of only a few years, would have impacted negatively on those involved in the production and trade of finished copper artefacts (similarly Waldbaum, 1978, p. 72; see also ErbSatullo, 2019, pp. 580-581 on a possible tin shortage in the LBA). A diminishing or challenged supply of tin would have had a significant destabilising effect on LC society. Local industries producing finished bronze artefacts would have suffered, and at the same time the critical need for tin may have given rise to new industries such as those exploiting scrap metal generally. All these factors may be read as signs of stress and the breakdown of social practices that previously played a considerable role in maintaining a stable state. Finally, the collapse of tin trading networks may have resulted in correlated impacts on the movement of copper, particularly if the 'crisis' affected whatever political entity controlled bulk copper production on Cyprus.

\section{Climatological Reconstructions-A Drying Landscape?}

Although the evidence is still provisional, it is possible that a drying environment could have acted as a stressor that impacted Cyprus during the transition from the Late Bronze to the Early Iron Age. Climate change, however, is a complex, multiscalar issue, and Finné et al. (2011, pp. 3154, 3168) rightly suggested that closer collaboration between archaeologists and climate scientists is essential for reliable historical reconstructions. The challenge here is to avoid viewing social change as a kind of black box: climates got drier and society collapsed, but the actual mechanisms of change remain vague.

Consequently, more care should be taken when arguing, as some have, that the LBA 'crisis' coincided with the onset of a 300-year-long period of drought that led to crop failures and famine, which hastened socioeconomic collapse and instigated large-scale migrations in the eastern Mediterranean (e.g. Kaniewski et al., 2013, p. 9; Kaniewski \& Van Campo, 2017, p. 90). Despite claims of high-resolution dating by the authors of these publications, Knapp and Manning (2016, pp. 102-107, figs. 1-3) demonstrated that the dates offered are sparse and lack adequate chronological resolution. In another, more recent paper that represents a step in the right direction, Kaniewski et al. (2019) presented ten radiocarbon dates from Cyprus and 19 radiocarbon dates from Syria that more or less correspond with the centuries in question (c. 1320-1025 BC, framed by $2 \sigma$ calibrations). These radiocarbon readings were taken from short-lived seeds and olive stones and referenced against pollen counts. Based on their analysis, the authors argued for a decline in agricultural 
production starting at $3250 \mathrm{Cal} \mathrm{BP}$ with the lowest levels of peak activity between 3150 and $2850 \mathrm{Cal} \mathrm{BP}$.

In their own paper, Finné et al. (2011, pp. 3162, 3167) reviewed 18 high-quality (but low-resolution) paleoclimatic proxies spread over the past 6000 years and, using a suite of dating techniques, identified arid conditions in the eastern Mediterranean both before and after c. 1200 вс. They acknowledged, however, that the proposed climatic date ranges can rarely be resolved to the point that they can be related to specific events. In a more recent, broader-based study of hydro-climatic variability throughout the Mediterranean over the past 10,000 years, Finné et al. (2019) observed that the climate 'oscillated' between about 4000 and 1000 BC $(6000-3000 \pm 300 \mathrm{BP})$, and noted that in the centuries around c. $1000 \pm 300 \mathrm{BC}$ the eastern Mediterranean became subject to what was, overall, the driest period during the Bronze Age (see also Langgut et al., 2013; Finkelstein et al., 2017). Thus, several proxy databases point to the possibility of more arid conditions in the eastern Mediterranean region at various times between the thirteenth and tenth centuries BC, even if precise dating and thus close synchronisation between archaeological data and specific historical events remain problematic.

If these environmental reconstructions are close to the mark, the mechanism of change on Cyprus seems fairly clear. In the island's semi-arid environment, there is evidence from historical eras that multi-year droughts have devasting impacts on agriculture, including famine conditions (Griggs et al., 2014, pp. 2710-2711; see also Iacovou, 2013, pp. 19-24). An extended period of lower rainfall would have exerted selective pressure working against the success of regional centres and larger villages whose economy was based at least in part on agricultural enterprises. The same pressure would have impacted on activity across the Cypriot landscape, setting important parameters within which the rural population acted. Thus, if such an episode of drought and diminished agricultural productivity actually occurred, it would have had far ranging impacts on Early Iron Age Cypriot society.

\section{The Material Evidence of the Early Iron Age (EIA)}

In the following sections we summarise the material evidence for Cypriot EIA settlements, mortuary deposits, rural shrines, industrial and craft production, and copper production and exchange.

\section{Settlement Evidence for the Early Iron Age}

Because settlement patterns provide a window on a society's political organisation and economic strategies, they offer a crucial form of evidence for understanding that society's integrative capacity. Following the widespread settlement disruption in the form of destructions and abandonments at the end of the LBA, only three townsEnkomi, Kition, Palaepaphos-survived; eventually they emerged (twelfth century BC) as prominent centres and probable seats of regional power. Even so, by c. 1100 
$\mathrm{BC}$ the hierarchical settlement pattern that had characterised the LBA had come to an end.

Figure 3 provides a snapshot of current settlement evidence on Cyprus from the thirteenth through to the seventh centuries BC. It is immediately apparent that the new towns-which ultimately became the centres of Cyprus's Iron Age polities-were not fully established until the ninth century BC or later, while nearly all the LBA settlements had been abandoned or destroyed well before these new centres emerged (Petit, 2019, p. 38). Excepting Kition and Palaepaphos, and to a lesser extent Idalion, none of the other Iron Age sites were settled during the LBA. In what Iacovou (2005b, p. 21) terms the 'urban-less environment' of the eleventh century $\mathrm{BC}$, the topography and social geography of Bronze Age settlements nearly faded from memory. The new Iron Age centres arose on sites with some strategic economic or locational advantage, whether on or near the coast (Salamis, Kition, Amathus, Kourion, Palaepaphos, Soloi, Marion, Lapithos) or inland (Ledra/Nicosia,
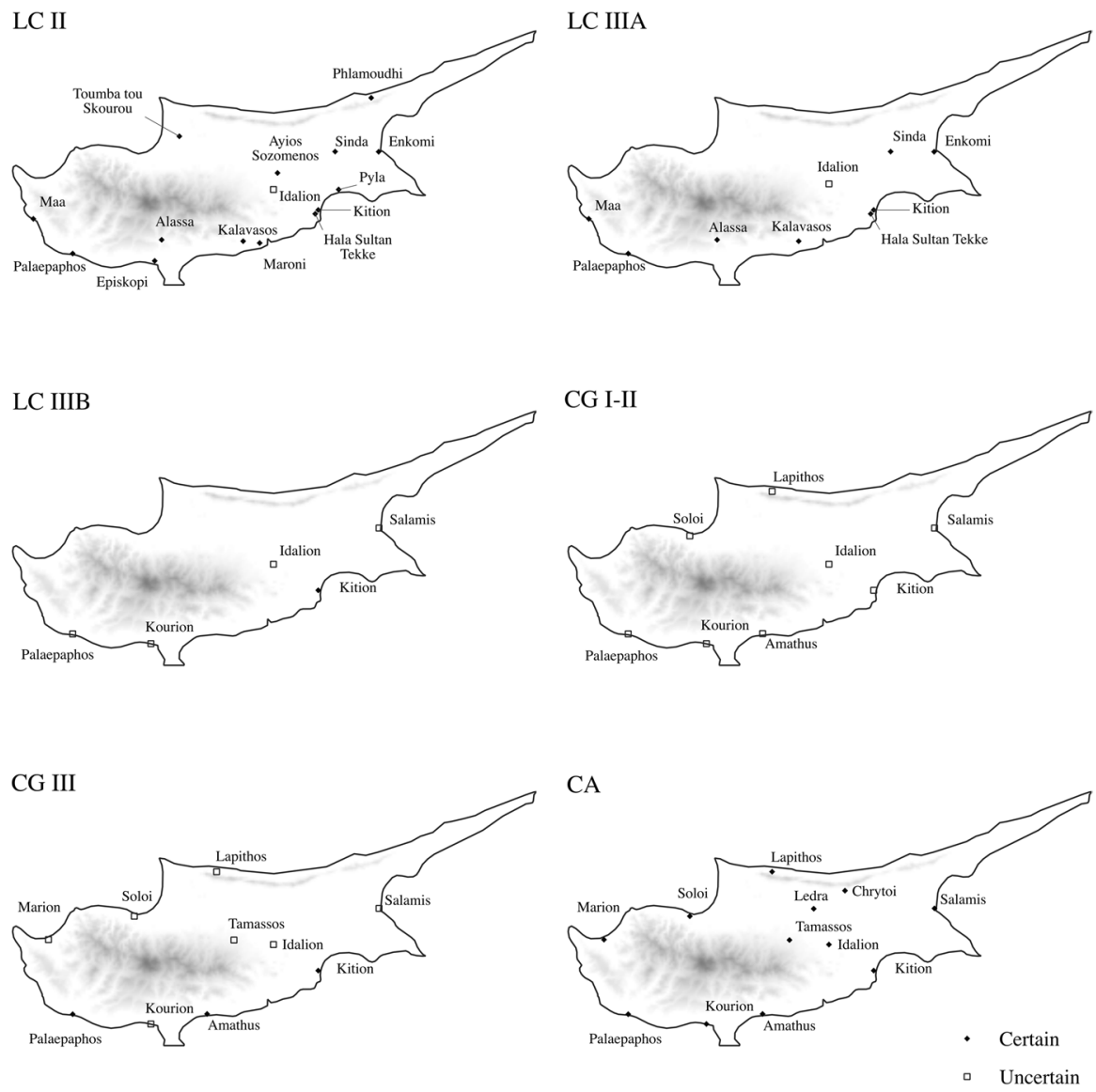

Fig. 3 Settlement sites on Cyprus by period (prepared by Nathan Meyer) 
Tamassos, Idalion, Chrytoi: Reyes, 1994, p. 160, table 2). That these locations, and likely the rationale for choosing them, might echo some locations of the LC period would support the Cypro-centric view of 'continuity' in the structure of economic potentialities. Potentialities, however, are not the same as actuality and, on current evidence, no continuity is evident in the settlement evidence; that is, activating these potentials appears to take place only after a period of discontinuity.

\section{Early Iron Cyprus-A Vacant Rural Landscape}

In addition to all the indications of destruction and abandonment, there is further evidence for settlement decline from the LBA, ultimately followed by expanding numbers and locations of habitation but only from the Cypro-Geometric (CG) III onward (Petit, 2019, pp. 36-37, 47, 56). This is attested in smaller, site-focused surveys, e.g. around Sotira (Swiny, 2004, p. 59), as well on larger, regional surveys. These larger surveys include the Paphos district (Rupp, 1987, p. 150); the northern foothills of the Troodos (Given \& Knapp, 2003, pp. 266-273; Given et al., 2013, p. 326), where the Iron Age is the least well represented period; the area near ancient Marion in the northwest, where in '... contrast with the Late Bronze Age data, survey evidence for the early part of the Cypro-Geometric period in the Chrysochou valley is more narrowly distributed' (Smith, 2018, p. 176); the Vasilikos valley in the south, where there is no evidence of LC IIIB material, and where '.. the various phases of the Cypro-Geometric seem to mark a low ebb in the fortunes of the valley' (Todd, 2013, p. 120); and, finally, also in the island's south but east of Vasilikos in the Xeros River valley, where the Late Bronze and EIA phases are marked by abandonment, and where, after the demise of LBA urban centres in the nearby Maroni and Vasilikos river valleys, '... we attest no other urban centres in the broader region' and where 'only a thin scatter of possible Cypro-Geometric (c. 1050-750 BC) material has been recorded' (Papantoniou \& Vionis, 2018, pp. 50-51).

Further work is needed in the occupied, northern part of Cyprus before we gain an island-wide understanding of this settlement vacuum during the Early Iron Age. Kearns (2015, pp. 186-191) and Andreou (2016, p. 165) have both suggested that perhaps the EIA landscape was not actually vacant but was occupied by a mobile population with less permanent (and less archaeologically visible) settlements, along with an attendant subsistence level economy. Iacovou (2018, pp. 19-20), in marked contrast, does not perceive a devolution to a more impoverished agropastoralism, but instead believes skilled populations abandoned economically failed regions (e.g. the Vasilikos and Maroni River valleys) and were absorbed, with 'continuity', into urban centres such as Enkomi, Kition and Kouklia Palaepaphos (see also Georgiou \& Iacovou, 2020, p. 1144). Whether lowland rural landscapes were vacant, abandoned or inhabited by a mobile population, the intensity of agricultural production declined. If the ability to produce or acquire an agricultural surplus is a corollary to social complexity, then this situation strongly suggests diminished levels of complexity.

This brings us back to the question of a drying landscape and whether and to what extent drought conditions may have impacted Cypriot society. Any attempt to answer this question is hampered by a six-to-one ratio of (published) pre-Iron Age 
to Iron Age excavations that incorporate environmental data (Kearns, 2015, p. 109). Some recent work, however, is informative. Kearns (2015, 2017, 2019), for example, using carbon-stable isotope analysis on archaeological charcoal, has demonstrated that-for the Vasilikos valley and Maroni region-rainfall to support plant growth dropped around $1200 \mathrm{BC}$ with a return to wetter conditions only during the centuries between 800 and 600 BC. Kearns's (2019, p. 279) review of survey data links this increase in aridity with 'significant drops in settlement numbers' in the region during the early CG period (eleventh to ninth centuries BC).

Elsewhere Kearns (2015, p. 236) demonstrated that, for the renewed settlement growth beginning in the ninth and increasing in the eighth century $\mathrm{BC}$, '... distribution of assemblages that indicate larger multi-family settlements throughout the region indicate [sic] a re-investment in fields with good water drainage, with off-site areas suggestive of a productive rural economy that re-utilized slopes and managed water run-off'. She implies that these conditions likely underwrote renewed settlement in areas of copper exploitation (Kearns, 2017, p. 6, 2019, p. 283). Intensification of agricultural production beginning in the ninth and accelerating in the eighth century BC would have supported conditions for increasing social complexity. Kearns (2019, p. 281) finds evidence for this link between a surge in exploited landscapes and increased complexity in the mortuary data from CG III-Cypro-Archaic (CA) I cemeteries on 'previously unoccupied ground', which may well suggest new social claims to land.

\section{Mortuary Evidence}

Keswani (2004) carried out extensive analyses and interpretation of mortuary data from the entire Cypriot Bronze Age. Because what happened at the end of the Bronze Age informs us about the EIA, her work bears some scrutiny. Significantly, she noted the emergence of intramural burial practices at the outset of the LC period. She seeks to explain this change in two possible ways (Keswani, 2004, pp. 86-88, 140), either that (i) intramural burials reflect the lack of a cohesive community or that (ii) such burials reflect a lineage-based assertion of rights to certain productive facilities within the urban fabric.

The move to intramural, urban burials, however, was not evident in contemporaneous rural areas where traditional, community-oriented practices continued (Keswani, 2004, p. 86). Thus, the key factor differentiating extra- and intramural mortuary practices is not the time period but the urban environment and attendant social milieu. This critical point has been largely overlooked in recent discussions (cf. Webb, 2018, pp. 222-224): intramural burials are an urban phenomenon of LC settlements, not of Cypriot society writ large. Within the urban environment, moreover, mortuary practices are not entirely uniform; some tombs show the traditional Bronze Age practice of significant reuse over generations, including secondary reburials. Others contained only a small number of burials and appear to have been used for a relatively short period of time.

Keswani (2004, p. 143) also observed an overall decline in the costs (energy expenditure) of mortuary behaviour as the LC period proceeded. Nonetheless, at 
the transition from LC II to LC III (c. 1200 BC), she also noted that ' ... trade, copper production, and monumental and civic construction expanded to an unprecedented degree, [and] important changes in mortuary practice were underway'. These developments were likely related to a growth in specialisation within 'court and temple institutions and an associated rise in the numbers of officials, dependents, and functionaries whose status was more and more independent of membership, or claims to membership, in the ancient kin groups of the city' (Keswani, 2004, pp. 159-160).

Changes in LC mortuary practices are indeed closely tied to sociopolitical changes driven by the growth of the political economy and state-level complexity; they are most visibly at play in the urban sector. The breakdown of traditional community-focused practices, the rise of competitive claims to the means of production, and the overall decline in the social importance of burials all point to a profound reorganisation of LC society that was, ultimately, cut short by the turbulence of the twelfth century BC.

While considering the lack of evidence for cultic practices in the Early Iron Age, Hatzaki and Keswani (2012, pp. 321-322) rightly noted the importance of the LC IIIB shift to extramural burials, with their potential for procession and display. There was a sharp per capita increase of investment in tomb architecture and burial goods, accompanied by a continuing (but more limited) reuse of tombs, and the first appearance of cremation burials. Hatzaki and Keswani argue that such changes indicate an emerging new dynamic in which mortuary display once again played a key role in social signalling. This dynamic also seems evident in the abandonment of LC IIIA cemeteries in favour of new, IIIB cemeteries, for example at Palaepaphos.

There are three detailed studies of mortuary data extending from LC III into the CG period. Steel (1993a) considered 84 tombs from the LC IIIB and CG I periods. Rupp (1989) examined 209 tombs dated between 1050 and 475 BC. Janes (2008) treated 617 tombs of LC III to Cypro-Archaic (CA) I date from Salamis (28), Palaepaphos (169) and Amathus (420). To these three multiple-site overviews we can add a more recent single-site study of Lapithos (Diakou, 2018). The key findings of these researchers may be summarised as follows:

(1) Steel found that $19 \%$ of the LC IIIB-CG I graves could be deemed elite, based mainly on their quantity, diversity and specific types of burial goods, but also assessing tomb size and pronounced disparities in wealth. Her analysis suggests a simple, two-tiered social hierarchy, with the elite defining their social position in community burial grounds through competitive displays of wealth. Overall, there was a decline in the wealth of burials in LC IIIB, although Steel inferred that those interred in the cemeteries at Palaepaphos had more access to wealth in the form of metal goods and foreign objects, thus suggesting some regional disparities. Her appraisal finds support in more recent publications of the necropoleis at Palaepaphos Plakes and Skales (Karageorghis \& Raptou, 2014, 2016, 2019).

(2) Rupp adopted a quantitative approach, describing how CG and CA mortuary data might be used to infer sociopolitical dimensions. He found that overall counts and classes of burial goods declined from CG I through CG II and rose again only at the transition to the CA. He discerned a similar pattern in levels 
of stratification: a 'soft' three-tier in CG I, two-tier in CG II and CG III and a better defined three-tier emerging in CA I.

(3) Janes took an explicitly regional approach and found significant differences in mortuary behaviour (and thus sociopolitical processes) among the three major sites she considered: Palaepaphos, Salamis and Amathus. The implication is that no single event or cause lay behind the eventual formation of state-level complexity across the island. Rather the evidence Janes considered-pottery, metal goods, imports, scarabs, seals, and weights-points to site-specific dynamics (including external relations) and differing regional legacies from the LC period. Her analyses of the Palaepaphos material accords well with Rupp's model; at Amathus she sees a much more gradual build-up of wealth, hierarchy and status signalling. At all three sites she sees the CG III-CA I transition as the era of more intense social stratification.

(4) Diakou notes a similar pattern of social reconfiguration during the CG, largely echoing the pattern of CG I wealth and stratification, but with few if any changes in burial behaviour during CG II. During CG III, however, social stratification appears to 'harden' as access to disposable wealth was restricted within the community.

Clearly regional trajectories deserve more attention even if they largely conform to what appears to be a consistent overall pattern. While acknowledging the need for ongoing analysis, we suggest that current mortuary evidence for the EIA on Cyprus shows new LC IIIB burial patterns (and a corresponding social reconfiguration) continuing into CG I, some continuity with diminished wealth in CG II, and increasing wealth and stratification only in CG III, leading into CA I.

\section{Rural Shrines}

With respect to regional sanctuaries, our focus here falls on relational space, i.e. the contested space between peer-polities, which are also co-evolving political and cultural forms. The peer-polity interaction model (Renfrew \& Cherry, 1986) charts in part a fundamental process of early state formation, namely the negotiation of territorial boundaries in contested space. Papantoniou (2012a, p. 105) is thus correct to argue that it is 'impossible to separate the development of urban centres from the overall process of the organisation of territory'.

Papantoniou (2012b, p. 286) has noted the lack of material evidence for Early Iron Age rural sanctuaries; they appear mainly in CG III and then 'proliferate' in the CA period. Should we see this later spread of rural sanctuaries as the initial constitution of territorial states, or as an indication of their consolidation and maintenance? Addressing this question, Fourrier (2013, p. 104) argued that only in the Archaic period do we see '... a territorialisation process... one that led from fluid boundaries to the political, economic, and cultural organization of the countryside and its control by a centralized authority'. Using various lines of evidence, including ceramic and coroplastic (terracotta figurine) production, the proliferation of secondary sites, and signs of royal authority such as monumental buildings and statuary, Fourrier 
noted this would seem to point to a late (i.e. CA) crystallisation of community identity (see also Petit, 2019, pp. 29-31).

We would suggest that earlier, during the CG period, a much more fluid landscape was the norm. Papantoniou (2012a, p. 103) urges us to consider that much of the Cypriot landscape operated as 'liminal' zones. Rather than boundary markers, rural sanctuaries acted as points of connection, bringing together various people to negotiate cultural and economic forms (Papantoniou, 2012a, pp. 103-105). Papantoniou cautions that regional styles may be associated with '....material availability, technological considerations, and workshops' spheres of influence rather than with political or national entities' (Papantoniou, 2012a, p. 106). Papantoniou and Bourogiannis (2018) have now suggested that some sanctuaries may have acted as 'central places', mediating political relationships across the island. It stands to reason, then, that a role change for rural sanctuaries-from a point of connection to that of hard boundary-would come about only in reaction to renewed competition for resources, copper being an obvious example. Not only would there be a role change but also a corresponding increase (as shown in the evidence) as shrines delineated boundaries, particularly in highly contested geographies, such as the central plain (Mesaoria, 'between the mountains' in Greek) where 'the boundaries of significant city-kingdoms would have been located' (Papantoniou, 2012b, p. 238).

Here we come full circle back to broader patterns of settlement evidence seen in regional surveys. We certainly cannot conclude that the interior of the island was densely inhabited (which would have provided a possible reason for contesting space). Even if we accept that population centres established in the eleventh century $\mathrm{BC}$ went on to become stable urban forms, they do not—on present evidenceappear to have been set in a multi-tiered settlement pattern such as that evident in the LC period. Without such a settlement pattern, no case can be made for territorialised states in CG I and II. Thus, to the degree that one wishes to read rural shrines as spatial expression of urban power, the evidence indicates that territorial expansion and spatial control only became an issue during the latter part of the CG period. The increasingly prominent role of rural sanctuaries at that time is a sign of the creation and strengthening of new traditions meant to make more durable emerging new social relationships.

\section{Industrialisation and Craft Specialisation}

Our specific goal in this section is to consider whether any evidence exists for economic diversification, including signs of experimentation, successful or failed. Likewise, we aim to assess the volume of economic connections within and beyond Cyprus and how this compares with the end of the LBA.

\section{Pottery Production and Trade}

Any consideration of Cyprus during the later Bronze and earlier Iron Ages should consider pottery production as one possible vector in the development of the Iron Age political economy. According to Georgiou (2017, p. 221), during the final stages 
of the thirteenth and into the twelfth century BCE the "earliest attempt to "industrialise" ceramic production is characterised by the profusion of regional variations'. She also notes that '.. centuries-old ... wares of handmade manufacture dramatically deteriorated in both quantitative and qualitative terms' and that '[ $\mathrm{t}] \mathrm{he}$ production of wheel-made vessels of Aegean-style increased "exponentially" at the opening of the twelfth century BCE' (Georgiou, 2017, p. 221). This was a transitional time of technical experimentation with the fast wheel and the amalgamation of foreign and local influences. Sherratt (1994a, p. 67, 1998, p. 298) long ago argued that the industrialised production of pottery would have been a significant source of wealth for a diversified elite under increasing decentralisation of trade. Neutron activation analyses by Mountjoy and Mommsen $(2015,2019)$ indicate that locally produced, Aegean-style wares were traded across the island and extensively off-island at this time.

Sherratt (1991, p. 193) also envisioned a long process of integration, standardisation and quality control of pottery produced over the course of the twelfth century вС. During the eleventh century BC, this finds expression in the island-wide appearance of Proto-White Painted ware (Iacovou, 1988) (Fig. 4), the result of unified technical and industrialised production on the fast wheel (Iacovou, 1999, p. 150, 2005b, p. 35). Concerning five key wares (Proto-White and White Painted, Bichrome, Black Slip, Plain White, Coarse Ware), Steel (1994) argued for similar forms, standard decorative motifs, a common technology (the fast wheel) and even a fairly standard rate of deposition in tombs across the island (excepting Amathus, with respect to deposition rates). She concluded that regional variation had only limited expression, and that innovation spread across the island rapidly, indicating an island-wide and highly standardised ceramic culture.

Across this same time period (twelfth to eleventh centuries $\mathrm{BC}$ ), ceramic exports to the Levantine coast dropped off precipitously. Georgiadou (2018) suggests this was due to a loss of markets on the Levantine coast in the aftermath of site destructions such as that at Ugarit. Gilboa et al. (2015, p. 96) note a lack of clear evidence for LC IIIA imports and add that for LC IIIB and the transition to CG I '... no Cypriot pottery was shipped to the Carmel coast other than a few pithoi', a situation largely echoed farther north in the Levant. Elsewhere, Gilboa (2005), in making a

Fig. 4 Proto-White Painted

Ware stirrup jar from

Cyprus. The Metropolitan

Museum of Art Cesnola Collec-

tion, purchased by subscription,

1874-76 (74.51.1394). Image

courtesy of the Metropolitan

Museum of Art

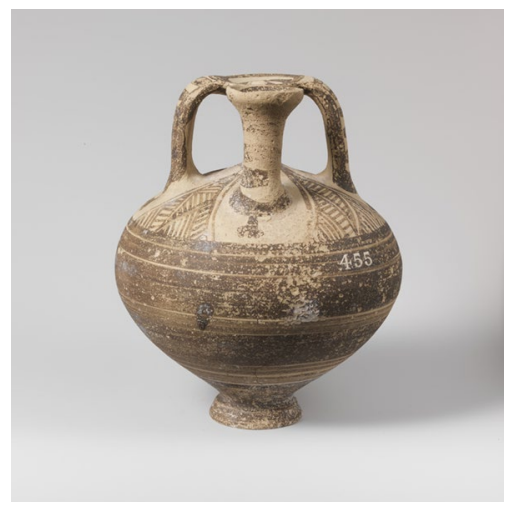


firm distinction between Phoenicia north of the Yarkon River and Philistia south of it, pointed out the extensive local production of Aegean-style pottery in Philistia and a resulting lack of trade relations with Cyprus. Lehmann (2017) suggested a similar pattern in Cilicia, where an 'overwhelming local' material culture contrasts with just a few possible LC III pottery imports (Taursus, Kazanli). Likewise, at Tell Tayinat, there are few known imports; the 'Aegean-style' pottery, with stylistic affinities with LC IIIB/CG I Enkomi, shows 'unmistakable signs of independent development' (Janeway, 2017, pp. 60, 149). Thus, while it is easy to agree in principle with Routledge (2017, p. 55) that some ongoing connections existed linking Cyprus, the Levant and Cilicia throughout the LC IIIA-CG I periods, the dominant impression is that pottery exports as a vector within the LC political economy diminished in LC IIIA and largely disappeared in LC IIIB. None of this demonstrates that Cyprus was not actively trading abroad during the LC IIIA-IIIB periods, but the trade in pottery was limited. If pottery production was a significant component of the LC III economy, it must have served local and intra-island markets, and was perhaps (as often suggested) predominantly for mortuary use.

Overall, then, there is evidence to support the idea of workshop-based, industrialised pottery production developing in the thirteenth century $\mathrm{BC}$, and perhaps accelerating during the twelfth century BC. The profusion of regional styles signals robust competition amongst competing centres, thereby creating a substantial new component within the political economy at the close of the LBA. Such economic diversification may be read as evidence of new and emerging social actors using innovative economic strategies. During the eleventh century $\mathrm{BC}$, the ceramic industry seems to have become broadly standardised. Unlike in the preceding and following periods, however, little pottery was exported: it was manufactured in an environment of decreased economic activity, in a highly standard fashion for a specifically Cypriot market. This implies not only a diminished political economy but likely also a change in mortuary practices meant to solidify an emerging new social reality. In LC IIIB, the broadly homogenous Proto-White Painted style, found across the island, signals a period of identity construction expressed in part through common mortuary practices - including a shared set of pottery styles.

Georgiadou (2012a, b) has begun to develop the notion of regionalism in CG pottery, constructing site-specific ceramic typologies, treating questions of style and examining three indices: technological, morphological and decorative. Based upon these indices, she has identified the cultural and territorial dimensions of regional centres and considered the degree to which such centres influenced each other. She suggests the resulting typological relationships can be read in terms of a 'regional hierarchy'. The likelihood that refined ceramic typologies will contribute to understanding the development of regional polities, specifically their timing, is of special interest. Nevertheless, it remains to be demonstrated more fully.

By the end of the eleventh century BC, Cypriot pottery exports (White Painted I, Bichrome I) once again appear, but only to the east (Iacovou, 1999, p. 149). At the outset of CG I, those observing this change nonetheless note that it seems to have served a much narrower market and took on a more 'personal' rather than commercial character (Gilboa et al., 2015, pp. 94, 100, citing the small amount of almost exclusively open shapes). This raises the question whether the lack of exports in the 
eleventh century BC, followed by a new mode of export in the earliest CG, indicates not only a significantly diminished political economy but also perhaps a mixed social and commercial role for exchange. Even as the CG period proceeds, however, and the range of pottery shapes expands to include closed vessels, the scope of exports from Cyprus does not constitute '... a commercial phenomenon of paramount importance’ (Gilboa et al., 2015, p. 101).

\section{Bronze and Iron Metalworking}

Although Cyprus was a significant exporter of copper during LC I-II, it was only during the thirteenth century $\mathrm{BC}$ that copper and bronze artefacts produced on Cyprus began to appear alongside various kinds of foreign imports as symbols of elite status (Papasavvas, 2012; Papasavvas \& Kassianidou, 2015). The hallmark of this newly vigorous metalworking industry was the production of technologicallyand artistically-refined bronze stands (Fig. 5). Yet this metalworking industry may not have been without substantial foreign competition from nearby Ugarit, where a cuneiform document (Ugaritic text RS 94.2401) seems to indicate significant numbers of similar objects (krkb, karkubbûma) being produced during the same time frame (Zukerman, 2012 refers to a metal production koine between these two neighbours; see also Artzy, 2006, pp. 17-19). Rather than focusing on whether the stands are a uniquely Cypriot creation that spread east and west, the more salient point here is that this Cypriot industry may have been in competition (or cooperation?) with Ugarit until the latter's destruction.

Fig. 5 Bronze rod tripod stand said to be from Kourion, Cyprus. The Metropolitan Museum of Art Cesnola Collection, purchased by subscription, 1874-76 (74.51.5684). Image courtesy of the Metropolitan Museum of Art

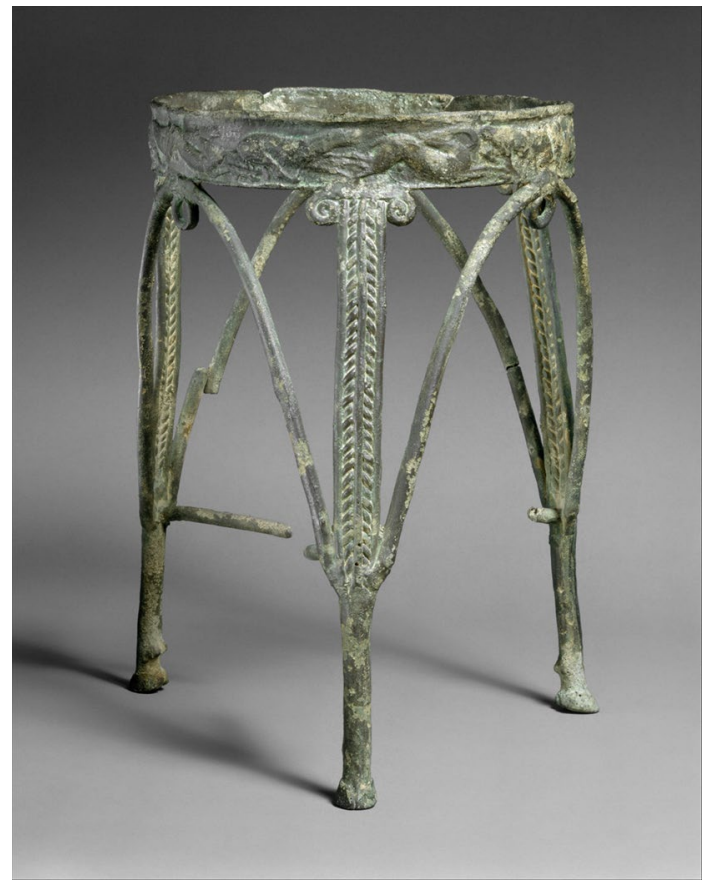


Cypriot production of stands may have carried on into LC IIIA (Karageorghis \& Papasavvas, 2001; Papasavvas, 2004) but there is no convincing argument that the technical and artistic levels achieved during LC II continued into the EIA. While the argument has been advanced that Cyprus was the 'dominant force' in the spread of a type of 'warrior burial' (Muhly \& Kassianidou, 2012, p. 125) and that this was the means by which the techniques and designs of bronze stands and tripod rods were transmitted to Crete, the actual production date of these stands remains uncertain. Papasavvas (2004, p. 35), looking at stands generally and specifically at those from graves at Palaepaphos associated with LC IIIB-CG I pottery, found no sound reason to suggest they date to that period; nonetheless he concluded it was reasonable to assume that they continued to be manufactured on Cyprus. Georgiou and Iakovou (2020, p. 1145) maintain that the presence of these stands in CG I-II contexts at Palaepaphos Plakes and Skales indicates that 'their manufacture continued well after the twelfth century'. In striking contrast, Catling (1984, p. 72) argued in great detail that the Cypriot metal stands were no longer produced after the early twelfth century $\mathrm{BC}$, and that any found in later contexts must be regarded as valuable, high-quality heirlooms. Be that as it may, the preponderance of bronze items from the EIA are of a decidedly more prosaic type and clearly demonstrate quotidian needs. That such items were not deposited in graves in large quantities beyond Palaepaphos implies that bronze was used conservatively. Given the present state of evidence, therefore, it must be concluded that while bronze metallurgy continued on Cyprus, it most likely did so at a somewhat diminished level of sophistication, which in turn implies a correlated loss to the political economy.

This loss of technical sophistication is echoed elsewhere. Steel (1993b, p. 153) noted that the Early Iron Age saw a '... decrease in extent and level of craft specialization in comparison with Cyprus during the Late Bronze Age'. Webb and Weingarten (2012, p. 92) stress that this time marks ' $\ldots$ the end (for some 500 years) of engraving stone and inscribed seals and a considerable diminution of stylistic diversity and technical skill'. Reyes (2002, pp. 218-219), moreover, noted that Early Iron Age seals did not reach the level of quality or provide indications of administrative function as they did for either the LBA or the CA period. The general decline evident in burial expenditure from the LBA into the CG period (excepting Palaepaphos) and the generally modest nature of CG burials at sites such as Amathus (Janes, 2008, p. 234) or Lapithos (Diakou, 2018) make it difficult to say much more about craft specialisation in the Early Iron Age. In itself, however, this is a meaningful observation: excepting pottery and, to a lesser extent, metalworking, craft specialisation during the Early Iron Age appears to have been in retreat across much of the island.

What was lost in bronze metalworking was perhaps replaced by iron metalworking. Various suggestions have been made about how iron production might have started (summarised in Muhly \& Kassianidou, 2012, p. 124), including that it may have resulted as an accidental by-product of copper smelting. It has also been proposed that an increasing lack of wood for fuel may have stimulated iron working, as iron smelting requires less fuel than copper smelting (Waldbaum, 1999, p. 42). Whatever the case may have been, there is little doubt that metalworkers on Cyprus had extensive metallurgical expertise as well as ample iron ore sources in the form 
Fig. 6 Iron knife, Enkomi (British) Tomb 58, Cyprus. British Museum, Museum Number: 1897,0401.994. (C) The Trustees of the British Museum

of iron-rich ochre and umber deposits (Muhly \& Kassianidou, 2012, p. 135). There is an extensive corpus of material from Cyprus associated with the production of iron artefacts during the Early Iron Age (Erb-Satullo, 2019, p. 567). On Cyprus, the ratio of iron to bronze, particularly for weapons and tools, increases steadily from the twelfth to tenth centuries $\mathrm{BC}$, and by the tenth century it would appear that for these categories of artefact, iron eclipsed bronze (Waldbaum, 1978, p. 47, fig. IV.6; Kassianidou, 2012, pp. 237-240).

This impression of an increasing use of iron on Cyprus, however, must be qualified by two points: (i) iron represents only nine percent of the total number of metal items from these three centuries; and (ii) the number of artefact types made from iron remains very low relative to bronze (Waldbaum, 1978, p. 29, table III.2, still a key work on the topic). For example, by the tenth century BC, iron is on a par with bronze for weapons whereas for tools (iron is found primarily in the form of knife blades) and jewellery (found primarily in the form of straight pins) iron does not show the same variety of types (Waldbaum, 1978, p. 47). Iron artefacts do not follow a clear pattern of appearing first as luxury or exotic items and afterwards as utilitarian items or tools (Palermo, 2018, p. 209). This seems evident from the distinctly different ratios and types of artefacts produced in the Levant versus those made on Cyprus (Walbaum, 1978, pp. 27-31, tables III.1-III.3). These tabulations indicate that the production and output of Cyprus's iron industry was at variance with that in the Levant, most notably in the manufacture of iron knives (Fig. 6).

Palermo $(2018$, pp. 251, 256) has noted that the rapidity with which the industry emerged and spread across Cyprus during the twelfth century $\mathrm{BC}$ was unique, as was 
its provision of both utilitarian and prestige objects. She concluded that experimentation and production in iron metallurgy developed and expanded rapidly in urban centres (Enkomi, Kition, Palaepaphos) during the twelfth century BC, a phenomenon regarded as a purposefully commercial endeavour (Sherratt, 1994a). Palermo identified two broad phases of development in iron metallurgy. The first phase, LC IIIA and early IIIB, was typified by the application of iron to a small class of objectspins, ivory-handled spatulae and especially knives-and was focused on a local, elite audience (Palermo, 2018, p. 239). During the second phase, commencing in LC IIIB but continuing into the CG, iron became more generally available but also continued to be used for items associated only with elite burials (Palermo, 2018, pp. 239-241). Thus, starting in the twelfth and carrying on through the eleventh century BC, there was steady development in an entirely new sector of the Cypriot economy.

The twelfth century $\mathrm{BC}$ on Cyprus was an era of diverse economic activity (as noted above for pottery). At the same time, the production of finished bronze (especially bronze objects with high tin content) may have been challenged-intermittently and variably across the island-by a lack of tin. Such factors represent an ideal context for developments in iron working: a diverse, somewhat chaotic political economy coupled with issues affecting raw material availability both worked to spur the innovative metalworking of iron artefacts, which primarily targeted a rapidly evolving internal elite but quickly expanded into more general, utilitarian uses. This development was not merely economic but also social in nature as it was driven by new social actors, likely acting independently.

\section{Copper Production and Trade}

Citing a recent study (Kassianidou, 2004, pp. 39-40) that presented evidence for mining in the Tamassos region, Satraki (2012, p. 274) suggested that '... mining and smelting activities were continuously practiced throughout the Early Iron Age'. The dates upon which Kassianidou's conclusions were based have now been published in full (Kassianidou, 2013, pp. 73-74, appendix I). At 95\% confidence level, the date ranges extend from 810 to $408 \mathrm{BC}$ (i.e. from CG III through the CA); these samples therefore cannot be associated with the 'early' Iron Age. Moreover, only two of the 45 radiocarbon dates published by Kassianidou (2013) could be as early as the tenth century вс: these are charcoal samples from Kambia (1016-412 вс, 95\% confidence level) and from Kition (1014-732 BC, 85\% confidence level).

Kassianidou (2013, pp. 63, 71, 2014, pp. 266-267) also argued that four radiocarbon-dated samples from Agrokipia Kriadhis (nos. 27-30 in her 2013 study) situate mining operations in the $\mathrm{CG}$ period and provide 'solid evidence for the continuation of the copper industry in the Iron Age'. The date range of these samples, however, extends from the late tenth century to the fifth century $\mathrm{BC}$, and so offers only the most tenuous evidence for any level of copper production on Cyprus during the eleventh and tenth centuries BC. Kassianidou (2014, p. 266) also cited other evidence-slag heaps, mining timbers, ropes - that is either inconclusive or of later date (ninth to eighth centuries BC). Yahalom-Mack (2017, p. 457) also noted that evidence for Cypriot production is 'particularly 
scarce' at this time and that such metalworking data as exists (from KitionKarageorghis \& Kassianidou, 1999) points to recycling.

It should also be noted that lead isotope analysis of a plano-convex ingot (METB55) from Hazor in the southern Levant, consistent with production from Cypriot ores, is dated to the ninth century BC (Yahalom-Mack et al., 2014, pp. 171, 174). Yahalom-Mack and Segal (2018, pp. 326-327) maintain on the basis of results from chemical and lead isotope analyses on several objects from four different settlements in the southern Levant that '... Cypriot copper ores were not used for the production of local artefacts during the Iron I'. Taken together with the lack of evidence for mining and smelting activities noted above, we suggest that at some point during the eleventh century $\mathrm{BC}$ the characteristic oxhide ingots of the LBA ceased manufacture, while the plano-convex ingot from Hazor may represent the production of a new, later, Iron Age form. The possible disruption in copper production on Cyprus in the eleventh-tenth centuries BC may have spurred copper producers in the Arabah (Khirbet en-Nahas, Timna) to fill the resulting, local demand (Ben-Yosef et al., 2012; Levy et al., 2012, 2018; Liss et al., 2020, p. 12; Yagel et al., 2016). Alternately, copper coming from the Arabah may simply have displaced Cypriot suppliers. That this displacement was profound is indicated by the recent discovery that Arabah copper was used for smelting at Olympia in Greece, at least from 950 to 750 вс (Kiderlen et al., 2016).

On Cyprus, if support from the state level of the LBA had been curtailed or ruptured, and/or the demand for Cypriot copper had fallen in the wake of events during the twelfth century $\mathrm{BC}$, the impetus to extract and produce copper for export, as well as the politico-economic organisation essential to realise it, would have plummeted. Based on the admittedly limited evidence available, it still appears that Cypriot copper production or trade on any significant level did not re-emerge before the ninth century BC (CG II) at the earliest. Moreover, evidence from northern Troodos sites such as Agrokipia Kriadhis, Politiko Kokkinorotsos and possibly Tamassos (Given \& Knapp, 2003, pp. 64-74, 136-46; Knapp, 2008, p. 296) suggests that the production of copper only reached significant levels once again toward the end of the CG or the beginning of the CA period (see also Petit, 2019, pp. 32-33). If wealth accumulation was based to any extent on copper mining, production and trade, territorial control would have been essential. The establishment of territorial boundaries in CG III therefore probably does not represent the consolidation of pre-existing kingdoms (Fourrier, 2013), which presumably would have had uncontested access to distant metal ores. Rather, such boundaries represent territorial extensions coinciding with the re-emergence of state-level complexity, the impetus arguably being a resurgence in copper production.

Having laid out both the stressors at work in LC society and the material evidence for early Iron Age (IA) Cypriot society, we next analyse this evidence with respect to the nature of the transition between the two periods. Before doing so, however, we turn to a brief discussion of the social aspects of Complex Adaptive Systems (CAS) theory, highlighting features that we use as an interpretive framework for understanding the LBA/EIA transition. 


\section{An Interpretative Framework: Complex Adaptive Systems (CAS)}

Since first introduced by Walter Buckley (1968), CAS theory as applied to human society has had a clear set of core concepts, preeminent among which, in our view, is the foregrounding of resilient, networked social actors whose adaptive behaviour forms the genesis of social change. This is not to say that fixed structures, such as geography and geology, are irrelevant; nor in fact are co-dynamics such as environmental degradation or the particularities of specific historical events (e.g., in our case, the destruction of Ugarit c. 1200 BC). Indeed, all of these factors represent stressors (whether as opportunity or calamity) to which social actors respond.

Complex Adaptive Systems (CAS) theory and the closely related concepts of resilience and adaptation (and adaptative cycles) have received increasing attention in anthropology and archaeology, including overviews and a recent special issue dedicated to these topics (Lansing, 2003; Kohler, 2012; Barton, 2014; Bradtmoëller et al., 2017a, b). Lansing (2015, pp. 11-12) claims that the mathematics behind CAS theory allows us to overcome the decades-old 'positivist dispute' and transcend a statistical analysis that merely mirrors social systems; the case study offered, however, was that of contemporary human-environment interaction. Barton (2014, pp. 310-311) has expressed concern regarding archaeology's ability to generate appropriate data for agent-based computational modelling typical of CAS theory; nonetheless, first examples have appeared (Bernabeu Aubán et al., 2012; Marsh, 2016; Symons \& Raine, 2009), including one focused on Bronze Age Cyprus and the emergence of social complexity from 2400 to 1700 BC (Swantek, 2017). Barton's evidentiary concern is particularly apt for Early Iron Age Cyprus. Nonetheless, although it might be tempting to undervalue 'weav[ing] CAS phrases into the narratives' (Barton, 2014, p. 310), we feel that the concepts behind CAS are far more than mere 'phrases' and carry a strong heuristic value that has already proven useful-e.g. for ancient Egypt (Lehner, 2000), Bronze Age Crete (Knappett, 2009) and the Iron Age Levant (Porter, 2013, p. 135).

In the term CAS, 'complex' refers not to complex society but instead to the relational nature of a CAS and its properties, such as power laws, non-linearity and emergence. In what follows, we highlight these and other key concepts useful in interpreting the archaeological evidence.

\section{Networked and Adaptive}

Social actors are embedded in a networked matrix of groups and sub-groups that is segmented and nested (e.g., an individual within a family, a family within a clan, a clan within a tribe). The network is pyramidal in the sense that smaller units cluster to create a larger unit; these large units then cluster to create an even larger one. The networked relationships are manifested as social practices; such practices convey information between the social actors and that information is 
constantly evaluated as individuals and groups act to acquire or preserve something of social or economic value. Social actors (individuals, groups) are always being influenced by and responding to stressors in their environment, broadly construed.

These qualities result in three implications of special interest. First, because networked relationships are stronger within a group than between groups, when a CAS becomes unstable, a key feature is an ability to 'uncouple' and 'devolve' into its constituent parts. Secondly, adaptation means experimentation (the generation of variability to previous norms). Finally, stability returns as adaptive experiments become new norms defined by new (or renewed) traditions embodied in social practice. The strong element of adaptability within a CAS also allows for periods of less or more rapid change and thus is eventful and punctuated.

\section{Emergent}

The sum of the mostly stable networked relationships that make up the social matrix is constitutive of a 'social structure'. A key concept of CAS theory, however, is that of emergence, that is, the bottom-up creation of large-scale patterns not directly intended by social actors. When applied to archaeological phenomena such as the homogeneity of material culture or the patterning of settlements, we consider bottom-up emergence as well as top-down prescription.

\section{Unequal Distribution}

Power-law or power-law-like distributions (very many small values and very few large values) are said to be ubiquitous in CAS. In the context of human society and of this study specifically, the focus is on unequal distributions such as in wealth, settlement size and network connections. Power-law distributions are an observable outcome (for example, wealth disparity) with social implications, but we are also interested in the mechanisms by which the distribution emerges. As a practical example, a person with many connections will find it easier (via attraction) to add a connection than someone with few connections. At a certain point, the disparity that emerges, in wealth or network connections, becomes hardened and self-perpetuating. One feature of power-law distributions in social networks is the catastrophic effect when a node (or nodes with the most connections) is eliminated. Radical changes of this kind can 'reset' how attraction works in the network, thus allowing a new pattern of connections to emerge.

\section{Complex, Nearly Chaotic}

Noting again that 'complex' is not equivalent to complex society, here we highlight concepts derived from $\mathrm{N} / \mathrm{K}$ networks. If $\mathrm{N}$ is the number of nodes (individuals or groups) in a network and $\mathrm{K}$ is the number of connections to self or other nodes, modelling has demonstrated three states for that network: ordered (completely stable, no change), complex and chaotic. A completely stable network $(\mathrm{K}=1)$ is 
characterised by isolated loops and the inability to change when external circumstances change. Where $\mathrm{K}$ exceeds 2 , the network experiences more disorder until reaching a point where any external change sets off instability. Where $\mathrm{K}$ is approximately 2 , complexity emerges. A complex network is capable of absorbing external change by adapting and settling into a new, stable form.

These concepts are powerful in their generality; the flexibility of the model allows for wide application and case-specific variability (Marsh, 2016, p. 124). Again, a social understanding of CAS foregrounds actors in an adaptive network of relationships.

We turn now to consider the different social actors who were embroiled in the dynamic period of change represented by the transition to the Iron Age on Cyprus.

\section{Differing Social Actors, Differing Impacts of Change}

To understand change, it is crucial to discuss the people involved: it is the human actors, relying on the resources and traditions embedded in society and responding to stress in the environment, who are capable of 'acting otherwise' (Giddens, 1987, 216). And it is the ongoing, unfolding of acting otherwise that results in change.

\section{Documentary Evidence for Cypriot Social Actors}

Documentary evidence (cuneiform letters and administrative records, Egyptian literary document) reveals that the social actors of LBA Cyprus included farmers, miners, craftspeople, royal and religious administrative personnel, merchants, diplomats, kings and a princess (Knapp, 2008, pp. 307-335). Different types and rates of change would have affected such people differently; for example, if copper exports declined, a miner would have fared worse than a farmer, and religious personnel would have been affected only inasmuch as ideology changed. Fourteenth and thirteenth century вс cuneiform texts from Ugarit (Syria), the Hittite capital (Boğazköy) and Egypt (Amarna) all reference a king and viziers from Alashiya (Cyprus), who were engaged in state-level trade relations (Knapp, 2008, pp. 309, 311, 313). Some of the fourteenth century BC texts from Amarna in Egypt mention messengers from Alashiya who functioned as ambassadorial merchants, amongst whom some had the power to negotiate terms of exchange (Knapp, 2008, p. 318). From Ugarit and Amarna, there is also mention of Alashiyan individuals-merchants, craftspeople and religious specialists (Knapp, 2008, pp. 318-320), some of whom seem to have been of diverse 'ethnic' makeup.

Putting these social actors into a matrix of relationships is more challenging. Various arguments exist concerning the sociopolitical organisation of LC society (Knapp, 2013, pp. 432-447). Here we simply reiterate the well-documented view that by the fourteenth century $\mathrm{BC}$ Cyprus was ruled by a single political entity, one capable of marshalling the labour and trading relationships needed to export significant volumes of copper, but one that may have been challenged by evolving elites in the increasingly complicated geopolitical context of the eastern Mediterranean. In 
what follows, we focus on some general concepts that facilitate discussion of social change: the nature of elites, the diverse and increasingly competing spheres of economic activity, and the uncoupling of the socioeconomic system.

\section{Differing Types of Elites}

Elites could only ever have formed a small fraction of the total populace. Although there are no good estimates for Cyprus, we might consider the case of LBA Pylos in Greece. There, archaeological data combined with analysis of Linear B texts indicate that $2 \%$ of the populace ( $6 \%$ of the adult male populace) is named in royal administrative texts and therefore likely to be elite social actors (Nakassis, 2013, p. 156). This puts some cautionary context around suggestions that in the latter half of the LC II period at Enkomi, most residents had some pretensions to elite status (Keswani, 1989, p. 68).

Elites were not monolithic and arguments can be made about possible different types. The material evidence suggests that LC II (c. 1450-1250 BC) urban forms varied across Cyprus, from agglomerative, diverse and externally oriented environments such as that at Enkomi or Kition, to possibly more hierarchical social environments that emerged less rapidly from agricultural communities such as those found at Kalavasos Ayios Dhimitrios and with the Maroni urban complex (Manning et al., 2014). At Ayios Dhimitrios, there are signs of entrepreneurialism emerging from a long history of incremental agricultural intensification (Andreou, 2016, p. 162). At Alassa Paleotaverna, elites not only controlled agricultural resources and a large labour force with architectural and craft expertise, but also enjoyed intraregional and international exchange contacts (Hadjisavvas, 2017, pp. 467-470). Thus, diverse kinds of elites occupied nodes in the overall political economy: some were tied closely to off-island trade; others were more involved in overseeing copper extraction, production and transport; still others were associated with agricultural or finished goods production. Such differences in both the type and position of elites set the conditions for experimentation in the face of environmental stress.

The above-mentioned nodes in the political economy sat in interlocking exchange networks (Fig. 7) that operated at different levels and with differing degrees of formality (Andreou, 2019). Individual social actors, particularly among the elite, participated in more than one system of exchange. Different patterns of exchange, as well as different types of elite, would have responded differently to environmental stressors. Consonant with our understanding of CAS, these different exchange networks, when under stress, could have uncoupled and subsequently been reconfigured. In contrast, long-standing local exchange networks, less formal and rooted in agropastoral traditions (following Andreou, 2016, 2019), would have endured. Both the uncoupling and reconfiguration of the more formal networks and the endurance of less formal networks are socially transacted forms of resilience.

The uncoupling under stress, however, would have been realised not only along the lines of economic networks. In the broader Levantine context, the household has been considered an important social construct (e.g. McGeough, 2007; YasurLandau et al., 2011; for Cypriot examples, see Knapp, 2003; Peltenburg, 2012, pp. 13-17). Households operated not only on a small, familial level but also in 


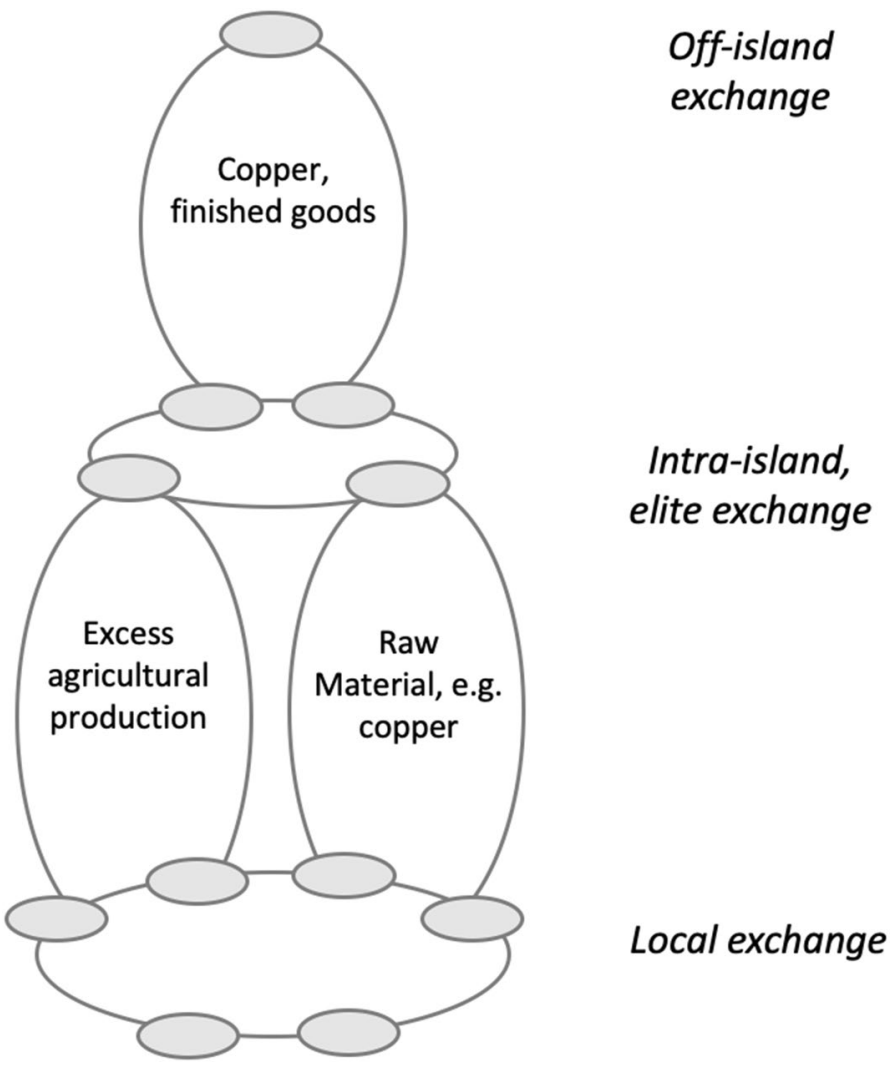

Fig. 7 Interlocking exchange networks (prepared by Nathan Meyer)

larger contexts well-integrated into the local, regional and state economy (McGeogh, 2007, pp. 74-75). For example, the large households of two elite, non-royal merchants of Ugarit-Yabninu and Urtenu (McGeough, 2007, pp. 75-77; Knapp, 2018a, pp. 112-114)—were both dependent on the palace, performing specific delegated tasks, but also independently engaged in a number of mercantile ventures that, while overlapping between the two households, were still distinct. These two complex entities illustrate an important point: while firmly entrenched in the affairs of the Ugaritic palace and thus playing an important role in the functioning of the state, at the same time they were largely independent economic entities functioning as self-contained sub-groups within the overall construct of Ugaritic society. Under stress, these households may have lost some external relationships but would have retained internal cohesion and represent the building blocks for subsequent reconfiguration.

We have referenced research into social actors in the Aegean and the Levant in the attempt to highlight certain concepts that, within reason, may be applicable more generally: e.g. differing levels and types of elites, distinct but interlocking exchange networks, the role of the household. To what extent is all this applicable 
to issues of resilience and adaptation on Cyprus? With that question in mind, we turn now to a discussion of the Early Iron Age on Cyprus, viewed through the interpretive framework of social actors and CAS theory.

\section{Early Iron Age Cyprus: Social Actors in a Complex Adaptive System}

Adherents to the Cypro-centric view seek to position their work as grounded in the longue durée of the Annales thinking associated with Braudel and others (on Cypro-centric views, see Papantoniou \& Vionis, 2019, and others discussed in the 'Cypro-centric' section above; on Annales in the Mediterranean more generally, see Bintliff, 1991; Knapp, 1992a) On the one hand, insofar as their view is related to marginal agricultural potential and an over-dependence on external trade as inhibitors to increased complexity within Cypriot society, we would agree. On the other hand, we feel that another Annales concept is more appropriate to the LBA/early IA transition, namely conjoncture, with its connotation of multiple independent but related phenomena and the emergence of rapid social change (Knapp, 1992b, pp. 6,11 table 1.1). Whereas the tendency has been to focus on external factors associated with the broader sociopolitical crisis in the eastern Mediterranean, we argue for cycles of instability and stability within the CAS that was Cypriot society. As noted above, CAS are not solely a phenomenon of a more complex society; all the periods discussed below represent complex and adaptive systems. Once again, we begin with the LBA (LC IIC), as it is critical for informing what follows, but our goal is to arrive at the Cypro-Archaic with due witness paid to the scale of social changechange brought about by social actors responding to various stressors-across the intervening centuries.

\section{LC IIC: Increasing Wealth Disparity and Network Connectivity}

Mortuary evidence from LBA Cyprus demonstrates that social inequality and wealth disparity increased dramatically throughout the period (Knapp, 2018b), and accelerated during LC IIC. Early in LC IIC, there are signs that locally powerful social actors were emerging. At Maroni Vournes, for example, Manning (1998) argued that a 'radical new power structure' focused on a single individual emerged at the outset of LC IIC. In turn, Keswani (1997, pp. 222-224) maintained that at LC IIC Enkomi, copper production took place on a 'previously unprecedented scale' alongside a number of 'extremely rich high status burial assemblages'. LC IIC also sees the rise of industrialised pottery production in regional centres as an expressly economic activity (Sherratt, 1998, pp. 297-298, 2003, pp. 42-43). At the same time, a vigorous Cypriot bronzeworking industry (Papasavvas, 2012, p. 120) served growing numbers of newly wealthy social actors. The variety in all these forms of wealth disparity represents the expansion of the political economy beyond the bulk trade in copper.

Correlated with this rise in wealth disparity, network connectivity increased in scale (numbers of nodes with increasing connections), with respect both to 
independent exchange relationships (Keswani, 2004, pp. 143, 154-57) and to the integration of local networks (Andreou, 2015, pp. 397-412). In other words, a growing number of social actors propelled the production of new goods that fed into an expanding internal economy, which in turn helped to forge new external connections. This is amply attested by the volumes of Cypriot pottery found around the eastern Mediterranean (e.g. Artzy, 1985; Merrillees, 1968; Sherratt, 1998, 1999). Van Wijngaarden (2002, pp. 275-277, following Hankey, 1967, pp. 146-147) suggested that Cypriot traders may have been responsible for the shipment of both Cypriot and Aegean pottery to the Levant, while Kassianidou (2003) argued that Cyprus likely controlled the tin trade during this pivotal period. What emerged was an ever-growing number of Cypriot social actors involved in more numerous and also increasingly distant overseas connections.

Wealth disparity is one expression of the phenomenon of power laws, where many individuals have very low values and a few have very high values (here, disparate wealth). In and of itself this may not drive instability, but what does drive it is the increase in network connectivity and communications, as new social actors seek to obtain wealth. As noted, stability erodes as the number of connections increases relative to the number of nodes. Wealth disparity and instability (or rather experimentation, which is a symptom of instability) is palpably evident in LC IIC mortuary data: towards the close of that period, burials are marked by increasing variety and demonstrate both relative poverty and wealth. Thus, it seems that a hallmark of the LC IIC period was an increasing social fragmentation driven by diverse economic strategies employed by independent social actors with increasingly distant network connections. Such instability must have affected the 'crisis' within and beyond the island and certainly was amplified by it.

At the close of LC II, Cyprus was some form of hierarchical polity that was involved in foreign correspondence, had political relationships with surrounding states, and was heavily invested in state-sponsored trade. If one places weight on the evident lack of a clear palatial centre and the prominence of some regional urban centres, it may be that the specific form this island-wide polity took would have been one of relatively weak centralisation. This polity certainly did not outlast the Late Cypriot period; its demise was the result of a complex set of stressors. Environmental drying may have played some role on Cyprus, perhaps instigating some movement of people and causing local food shortages that would have created social unrest and weakened state authority. Certainly, the accumulation of wealth and power in the hands of social actors engaged in independent mercantile activities played a major role, as did disruptions in the trade in bulk copper and tin. A weakened polity stood no chance of survival when Ugarit was destroyed and with it a major node in the bulk metals exchange network. Because CAS are segmented and adaptive, the demise of the hierarchical polity on Cyprus-where the production and exchange of copper were major drivers of the political economy-resulted in the devolution of economic and social power to decentralised economic networks and households. 


\section{LC IIIA: An Unstable Continuity}

LC IIIA is widely regarded as a period of continuity from LC IIC, with no significant shifts in mortuary practices or in industries that flourished during LC IIC. Moreover, major new building programmes were undertaken in Palaepaphos, Enkomi and Kition. The emphasis on continuity, however, both risks missing the episodic nature of developments and perhaps also masks the likelihood that social complexity was slipping into the chaotic. Negbi (2005, p. 27), for example, proposed a cycle of urban growth and retreat over the LC II-IIIA periods. The existence of such cycles is of interest not only as a potential historical scenario but also from a sociopolitical perspective: it amplifies the argument for ongoing social experimentation that nonetheless proved unsuccessful in sustaining a stable urban society. Notable changes in settlement patterns indicate that parts of Cyprus suffered during LC IIIA. The abandonments and destructions evident across the island in the decades immediately prior to and following $1200 \mathrm{BC}$ demonstrate that the emblematic settlement pattern of LC IIC was disappearing and, along with it, the previously stable politico-economic regime. Crucially, relationships between differing types of settlements would have been disrupted constantly, along with the corresponding economic networks and social bonds.

Even where continuity of settlement is attested, profound change may be seen in the material record. At Enkomi, for example, a 'significant reorganisation' of its urban form took place (Manning et al., 2014, p. 9). Likewise, at Kition, ' $\ldots$ the sacred precinct was completely rebuilt on a grand scale' (Karageorghis \& Kassianidou, 1999, pp. 174-175). Given the 'unparalleled monumentality' (Iacovou, 2005b, p. 21) demonstrated in the building programmes at both Kition and Palaepaphos, it has been argued that a strong central authority was actively planning and managing the change. As evident at Enkomi, however, instability was written into the archaeological record: continued destructions and re-buildings typify the LC III period, possibly the result of ongoing power struggles between different factions (Keswani, 1997, pp. 225-226).

The sites of Maa Palaeokastro and Pyla Kokkinokremos (on the latter, see now Bretschneider et al., 2021), founded at the transition from LC IIC to IIIA, can best be understood in this context of broad cultural continuity but significant instability. Whether we interpret them as breakaway sites or as being under the mantle of nearby Palaepaphos and Kition, respectively, these settlements-established during a time of increasing instability and abandoned within a few decades-provide strong testimony to the ongoing experimentation by Cypriot social actors in the face of social breakdown and increasing insecurity.

Throughout LC IIIA, this turbulence is also seen in changes in the political economy. Already by the end of LC IIC, industrialised agricultural settlements such as Maroni and Ayios Dhimitrios were abandoned. Elsewhere, the trend toward industrialisation in pottery production, well established in the previous period, accelerated alongside increasing integration of forms. At the same time, however, pottery exports rapidly declined. This combination of steady industrialisation and the absence of exports resulted in an adaptive strategy taken up by this 
inwardly focused industry, which eventually resulted in the ceramic homogeneity that became a hallmark of LC IIIB.

Likewise, continuing attempts by elites to adapt to changing conditions and establish a viable economic strategy are clearly evident in metalworking. At the same time that workshops were challenged to find tin for high-quality bronze, the introduction, rapid development and expansion of iron working took place. Ironworking represents the last major innovation of Cypriot culture before the ongoing calamities both on and off the island simply proved to be too much, leading to 'an apparent economic downturn' (Sherratt, 1994a, p. 74).

While there is no evidence to support a massive influx of Aegean people, it is likely that there were new arrivals from both the Aegean and the Levant, if not from farther afield (Bretschneider et al., 2021; Bürge \& Fischer, 2019). As a result, Cypriot culture in the twelfth century $\mathrm{BC}$ had myriad external influences, all fully intermixed within the local context. This dynamic remixing likely included shifting internal and external relationships between new and differing sub-groups within Cypriot society. The role this played in weakening earlier social bonds and forging new ones cannot be overstated. Some of these bonds may have been predominantly off-island but also would have resulted from new economic ideas and activities generated by the multi-cultural mix. As indicated by the diversity of pottery at Maa Palaeokastro (Mountjoy \& Mommsen, 2019), the regionalism evident in LC IIIA pottery (unlike the case in the CG, for which see below) is not an indication of a breakdown in intra-island networked connections: instead, it is a sign of diversity among the economic actors involved.

The shock caused by the collapse of the trade in bulk copper cannot be underestimated. The impact of this collapsing trade in copper-its extraction, production and transport-on social actors in Cyprus would have been severe. By analogy with Timna or the Arabah, where subsequent mining has not thoroughly destroyed earlier evidence (Ben-Yosef, 2016; Levy et al., 2018), entire communities seem to have functioned solely around the mining and smelting of copper. Given the amount of copper involved (Knapp, 2013, p. 444), it seems evident that certain people had specific, dedicated roles in industrial and transport processes. In turn, this specialisation resulted in diverse economic roles for social actors involved in the production of agricultural and other essential resources (e.g. Andreou, 2019).

Thus Cyprus, a key exporter of copper during the LBA, must have had people whose roles and degrees of specialisation within and beyond the copper industry would have evolved into dominant social practices driven by copper production itself. When the production and exchange of copper declined, however, these roles and the industrial processes in which they were embedded were decisively affected. Cypriot elites closely tied to the bulk production of copper would have been even more negatively impacted if the export of copper declined rapidly. If the fall-off was less precipitous, these same elites would have had opportunity to extend or strengthen other social roles. The 'crisis', to the extent it affected Cyprus, was a slow, rolling series of disruptions across the end of the thirteenth and into the twelfth centuries BC, caused by multiple stressors that would have given some social actors and various economic sectors the opportunity to exhibit resilience and to adapt. This 
resilient adaptation is evident in hit-and-miss continuity from LC IIC as well as the diversity of LC IIIA economic strategies.

\section{LC IIIB: The Emergent Iron Age}

Just as some social actors on Cyprus adopted traditions borne out of LC IIC urban life and commercial activities, others looked to different repositories of traditional social practices, namely those rooted in rural lifeways that typified Cyprus before it entered into the 'globalising' world system of the LBA (Sherratt 2016b).

In the variety of LC II/LC IIIA mortuary practices, we see experimentation as a result of reconfigurations in Cypriot social dynamics. Specifically, the shift to an overall simpler mortuary practice (less grave expenditure, fewer secondary ritesSteel, 1993a, p. 165) may be equated with less information being transmitted across society through mortuary practices. A subsequent shrinkage in the political economy and the demise of state-level complexity, and the need to reconfigure the social matrix, might therefore be expected to drive a further change in LC IIIB burial practices. The results of this can be seen in a newly emergent and largely common mortuary practice that becomes evident across much of the island. This new (or revived) practice has three constituent elements: (i) a renewed focus on extramural burials in chamber tombs; (ii) burials in new cemeteries; and (iii) an increase in mortuary effort and expense. These represent a set of practices specifically designed to communicate and stabilise emergent social relationships. As noted earlier, the movement away from extramural burials was a phenomenon of urban (not rural) life on Cyprus. Yet LC IIIB burials are not identical to earlier practices as emphasis was no longer placed on deep familial lineage (Hatzaki \& Keswani, 2012, p. 322). Instead, this new development represents the integration of past traditions with new forms of identity focused on the immediate household if not the elevation of the individual. This is most evident in the practice, limited but attested especially at Palaepaphos, of cremation.

There is a second, complementary phenomenon, that is, the homogeneity of LC IIIB pottery. During LC IIIA, the standardisation of pottery production continued, both in terms of technique (fast wheel) and in its integration into a set of common forms. Although this goes some way towards explaining the pottery of LC IIIB, there may be a deeper, social explanation. It seems clear that off-island exchange dropped from LC IIC to IIIA and continued to wane in LC IIIB, which resulted in or was at least coincident with a diminished political economy on Cyprus. In this environment, commercial activity_by now diminished-focused on intra-island exchange and, critically, was directed toward people who would have sought to stabilise relationships within an evolving society. As noted above, it is not just the pottery technology that becomes common, but also the relative rates at which pottery forms are selected for and deposited in burials. The implication is that both the burials and the pottery are forms of information being exchanged by people across the network in support of evolving social relationships.

The society that emerged in the Early Iron Age was not without some level of wealth disparity. As noted above, there is ample evidence to show the existence 
of a simple, two-tiered hierarchy in mortuary practices. The segmented nature of CAS facilitates a tendency for society to disassemble under stress into its constituent parts. As the political economy shrunk during LC III, social relationships disappeared or became irrelevant (e.g., as noted above, those associated with bulk copper production). In their place came a new emphasis on the private household; some of these households may have involved families, engaged in trade, that survived the economic downturn (as in the contemporary Levant-Gilboa et al., 2015, p. 101, and the Aegean-Murray, 2020, pp. 202-204). These were the households that maintained or re-established external connections with similar households, within and beyond the island. In the Levant, with its long tradition of independent trade around the edges of palace-sponsored exchange, such families and households were likely entrepreneurial merchants. On Crete and in the Aegean, such families may have been drawn from the local, landed political elite (Antonaccio, 2016) and the exchange of prestige objects would have been undertaken along long familiar lines. On Cyprus, the wealthier burials appear to represent both types of households (entrepreneurial merchants and less mercantile and landed political elites); these groups came to the fore depending on very local economic strategies. Whether strictly familial or not, such households became the fundamental social building blocks of the Cypro-Geometric period.

\section{CG I-CG III: Contraction to Regeneration}

The emergent phenomena noted during LC IIIB attest to individuals acting to stabilise Cypriot society. This attempt at stabilisation, however, was happening against the backdrop of a general decline in the political economy, the resulting uncoupling of links within society and a 'devolution' and 'fragmentation' of political structures (Georgiou \& Iacovou, 2020, p. 1149). During the CG period, the political economy first underwent contraction and then regeneration. In the foregoing, we have presented the evidence for contraction in the forms of reduced material wealth in funerary deposits, a reduced level of commercial activity as measured by off-island pottery exports, and reduced rural settlement. Here, we revisit notions of emerging regionalism in pottery production and the rural settlement pattern for evidence of regeneration.

After the conspicuous gap in Levantine exports during LC IIIB, networked connections begin to reappear during CG I. An optical minerology study of Phoenician Bichrome pottery suggests that some of this renewed interaction was with sites on the south and southwest coasts of Cyprus (Gilboa \& Goren, 2015). As noted above, some have argued this exchange was more social than commercial in nature. Connections expanded in regionally specific ways as some households and communities were able to benefit from these connections while others were not. Georgiadou (2018), for example, has found that Levantine imports to different communities on Cyprus, and their deposition in tombs, varied along four different axes: (i) volume (from less than $1 \%$ to $10 \%$ of all ceramics); (ii) range and proportion of shapes (Amathus had the broadest range but Palaepaphos had a much higher rate of amphorae); (iii) which members of the community had access to imports (restricted to elite 
burials at Palaepaphos); and (iv) communities not networked to the Levant at all (Lapithos). Pottery production on Cyprus in the CG also reveals signs of regionalism after the homogeneity of LC IIIB, possibly with emerging centres of stylistic influence (Georgiadou, 2012a, b). In the language of CAS, as network connections fall below 2 and head toward 0 , isolated loops of communication develop as the network becomes uncoupled (Lansing, 2003, p. 189). This may well represent what we see in the CG, namely a generally diminished Cypriot society fragmented into local networks with variable but reduced off-island exchange.

Supporting the contention of a reduced political economy, data from regional surveys in several parts of Cyprus show diminished activity across the CG landscape. It could be argued-although there is as yet no direct evidence-that the decline in settlement numbers implies a decline in population. As attested by the mortuary data, the precise aspect and pacing of the decline was different region by region. The most detailed exploration of reduced activity in the landscape comes from the Vasilikos and Maroni valleys, where Kearns (2015, 2019), through a combined programme of aridity measures and resurvey, has shown that '... significant drops in settlement numbers in the early CG period (twelfth to ninth centuries BCE)' correlate with a drier environment. Kearns (2019, p. 280) adds that the evidence:

... suggests the clustering, or contraction, of communities ... limited permanent occupation with some preserved maintenance of important coastal trading sites and access to major transregional routes that connected the east and west of the island. ... By the late ninth to eighth centuries BCE, however, this apparent contraction of the local population is countered by the expansion of numerous re-settlements as well as original establishments, particularly tomb sites ... The distribution of these sites indicates the potential bounding of emergent communities ....

Kearns (2019, pp. 286-287) is careful to point out that additional work is needed to demonstrate the simple equation of wetter = better and thus (i) to affirm a resurgence of Cypriot society and (ii) to delineate how diverse social actors involved in exchange, agriculture and metallurgical activity responded to changing conditions. Such evidence is of critical importance for understanding the LBA-EIA transition and the resurgence of social complexity in the CA period.

It is unlikely to be a coincidence that an expansion in settlement coincides with what Janes (2013, p. 158) identified as both an increase in weaponry and osteological signs of stress and injury in CG III burials at Amathus. Increases in the spatial extent of newly settled communities likely involved growing conflict at the boundaries (Petit, 2019, p. 55 argues for a dramatic change in political organisation at Amathus at the end of the ninth century BC). Nor is it a coincidence that this period of diminished settlement across the rural landscape co-existed with a general lack of evidence for copper production and export. The earliest possible-and quite limited-evidence for renewed copper production only appears in the late eleventh or early tenth century вс at Kambia and Kition (Kassianidou, 2013, pp. 72-75) and, as noted above, evidence for the renewed export of copper is weak at best.

Kearns (2019, pp. 283, 286-87) not only finds evidence of expanded settlement space during CG III but also clear signs of social boundaries (e.g. in ritual spaces 
and networked communities). Finally, with respect to regeneration: it is during the CG III period and even more so in the following CA era that an increase in rural shrines becomes evident (Papantoniou, 2012b, p. 286). Such shrines represent ideal places for information exchange between people who were actively creating and developing new networked connections in the changing social matrix that becomes so evident during the CA period.

It is this combination of stressors in CG III (increased links between Cypriot and off-island communities, increased spatial conflict brought on by expanding rural settlements, changing social organisation resulting from renewed production and export of copper) that ultimately led to the formation of the CA polities. At the same time, the durable reality of Cypriot physical geography and the wealth of copper ore deposits must have played a conspicuous role, just as it had in Bronze Age state formation. Both these factors, however, must be set against the broader context of the Iron Age Aegean and eastern Mediterranean, to which we now turn in conclusion.

\section{Conclusions: Cyprus in its Regional Context}

As Knapp has argued frequently (e.g. 2013, p. 29), because the material culture of Cyprus always differs notably from that of surrounding lands, Cypriot pre- and protohistory must always be viewed from an internal perspective; in this respect, our argument might be deemed 'Cypro-centric'. At the same time, however, we can only understand internal developments on the island within the wider contexts of the Aegean and eastern Mediterranean. In the present case, moreover, it must be emphasised that we cannot relate the nature of the polity (or polities) of any one period on Cyprus directly to those of previous or subsequent periods. Thus, we reiterate as a first principle that the formation of Cyprus's Iron Age polities cannot be regarded as 'a close re-enactment of [a] Late Bronze Age politico-economic tradition' (Iacovou, 2002, p. 85), and nor can those polities be seen simply as some pale reflection of 'global' developments in the region.

In order to set the present discussion in its contemporary geopolitical context, we need to consider briefly the aftermath of decline in the polities surrounding Cyprus. In her recent study of the post-Mycenaean economy, Murray (2017, p. 276) maintains that although Greece never became particularly isolated from the wider Mediterranean world (in terms of imports), there were nonetheless 'deep and broad changes in social and political realities': large LBA settlements with significant levels of population and heavy investments in monumental architecture were replaced by generally impoverished sites with few notable monuments. Population declined by as much as fifty percent and life became a 'fight for survival' even as new institutions emerged that would eventually form the 'building blocks of historical Greece'.

The Aegean world of the twelfth through ninth centuries BC bore no resemblance to that of the palatial world of the fourteenth and thirteenth centuries $\mathrm{BC}$; the new sociopolitical order that arose (during the eighth century BC) seems "characteristic of those [who are] building complex societies out of scratch rather than reconstructing or building upon an immediate predecessor' (Murray, 2017, p. 276). The decrease in imports and exotic objects evident in the Aegean after the thirteenth century $\mathrm{BC}$ 
resulted not from supply-side issues but from the diminishing demand of a domestic economy that had become weaker and smaller (Murray, 2017, pp. 277, 279-80). The shrinking of the domestic economy after the end of the LBA led to other, major structural changes in the political economy and in the organisation of society overall. In sum, it appears that in Greece, if not in the wider Aegean, economic decline set in motion a long, drawn-out process of crisis and recovery, one that eventually resulted in a new sociopolitical order - the polis-which, like the 'city-states' of Cyprus, bears no resemblance whatsoever to its LBA forebears.

In the Levant, a series of destructions or abandonments mark the final Bronze Age levels of several coastal or near-coastal states, from Ugarit in the north to the Canaanite towns of the south. The task of characterising politico-economic transformations in Early Iron Age sites along this lengthy coastal corridor is far from straightforward, not least because (i) most archaeologists working in the region tend to see the 'appropriate unit of analysis to be something other than the Levant' (Routledge, 2017, p. 51) and because (ii) the area has become 'balkanized' into small, discrete culture-historical zones '... structured by modern national borders and disciplinary schools', and often regarded simply as a 'corridor' between more powerful polities situated to the east, west or south of the Levant itself (Porter, 2016, pp. 373, 403-404). Nonetheless, in the wake of the LBA destructions and abandonments, several small or mid-sized kingdoms emerged, a patchwork of independent polities that were ultimately dismantled or reconfigured in the wake of imperial aggression (Porter, 2016, pp. 373-374).

The contrast between the politico-economic organisation of Levantine LBA and most Iron Age polities is typically seen as a new development in Iron Age state formation, even if there are similarities as well as differences in their cultural developments, ethnic composition and structuring principles. The 'Phoenician' polities, of course, are traditionally seen as the direct, culturally continuous successors of the Bronze Age Canaanite city-states (e.g. Aubet, 2001; Markoe, 2000), but both the archaeological and documentary records reveal that the reality was far more complex (Monroe, 2018). Such structural diversity makes it difficult to offer any universal explanation, and most scholars have tended to develop local typologies to account for the diversity of Iron Age Levantine kingdoms (Routledge, 2017, pp. 59-60). Joffe (2002), for example, defined the Iron Age kingdoms of the southern Levant as 'ethnic states' but suggested that their integration followed rather than preceded state formation, which began as a strategy of emergent elites from the ninth century BC onward. In turn, Osborne (2013) argued that the rulers of polities in the northern Levant were seldom able to exercise their full authority over the territory they claimed.

In sum, communities all along the Levantine seaboard underwent transformation as regional states declined, resource acquisition strategies broke down and populations shifted. New relations of power had to be established and legitimised within specific spatial and historical contexts. As Routledge (2017, p. 66) put it, Levantine Iron Age state formation was a work of 'bricolage', not the unfolding of some preexisting sociohistorical or politico-economic process.

Given that entirely new politico-economic formations unfolded during the Early Iron Age in the surrounding Aegean and the Levant (as well as in Anatolia, not 
treated here but see, e.g., Muhly, 2003; Genz, 2013), one must question whether Cyprus was so unique as to be able to maintain its sociopolitical and economic structure(s) unchanged across the Late Bronze-Iron Age divide. Even if Cyprus weathered the transformations evident throughout the rest of the Aegean and eastern Mediterranean during the twelfth century BC, ultimately it succumbed to the changing geopolitical realities of the post-Bronze Age.

Moreover, it is not just the demise of the LBA geopolitical order that is of concern but also the regional advent of the Iron Age, with its less centralised, initially less robust and yet more entrepreneurial economy. Developments on Cyprus must be seen within this broader regional context. In keeping with the use of CAS theory to help articulate the changes, we maintain that the ways in which the people of Cyprus engaged with this new, broader Iron Age reality played a crucial role in its eventual internal reformulation. Although the island's physical realities and a wealth of tradition-agropastoral as well as industrial—forever inflected the forms of ancient Cypriot society, external connections played just as important a role.

At this time, it is difficult to tease much more out of the published archaeological record. Nonetheless, if the accumulation of wealth was based to any significant degree on the extraction, production and trade in copper, territorial control- that is, spatial power-would have been crucial. Thus, the establishment of territorial boundaries in CG III most likely indicates the extension of territorial control, including direct access to metal ores, that would have coincided with the re-emergence of state-level complexity.

The paucity of material evidence related to multiple social and politico-economic phenomena during the centuries between c. 1100 and 800 BC still makes it possible to claim either (i) that Iron Age 'city-states' became 'consolidated' around $750 \mathrm{BC}$ as a result of transformations that took place during the eleventh century $\mathrm{BC}$ and afterward; or (ii) that these 'city-states' represent new sociopolitical formations that only emerged during the ninth to eighth centuries BC. Yet there is little agreement beyond the notion that the formation of an established IA 'state' only came later, toward the end of the $\mathrm{CG}$ period. Based on the broad array of evidence from the Late Bronze and early Iron Ages presented in this study, however, we believe it is no longer viable to argue for any significant degree of 'continuity' between the two periods.

While we agree that a globalising and essentialising narrative of colonisation is misplaced, it should not be replaced with yet another narrative, based on a fatalistic determinism driven by deep structures of geography. Instead, the research agenda proposed here focuses on resilient social actors who not only responded to each other in myriad ways but also to their physical environment (geography and climate), to a substantially diminished and unstable political economy, and to a disrupted and limited off-island trade. In so doing, they made use of the affordances (material and social) of their particular locality, drawing upon the deep well of Cypriot tradition as well as new ideas from outside the island.

Finally, although Cyprus may have weathered some of the more disastrous effects of the long-term 'collapse' evident throughout the rest of the Aegean and eastern Mediterranean during the twelfth century BC, ultimately it too succumbed to the changing, more competitive, smaller scale, politico-economic realities of the Early Iron Age, not least concerning the demise of the highly specialised exchange 
systems that revolved in part around the production and distribution of Cypriot copper. There followed a period in which several smaller, local or regional polities emerged on the island, but we acknowledge that further research is required before we come to a fuller understanding of their political structure and social organisation.

Acknowledgements Our thanks to Thierry Petit, Catherine Kearns and Jennifer Webb for comments on an earlier draft of this study. We also thank both Petit and Kearns for providing us with recent or forthcoming publications related to the topic(s) of this study. Finally, thanks to the editor of JWP for a constructive dialogue on structure and details. All statements and conclusions remain those of the authors.

Author's Contribution NM (60\%); ABK (40\%).

Funding No external funding involved.

Availability of Data and Materials Based on published material.

Code Availability Not applicable.

\section{Declarations}

Conflict of interest The authors declare that they have no conflict of interest.

Open Access This article is licensed under a Creative Commons Attribution 4.0 International License, which permits use, sharing, adaptation, distribution and reproduction in any medium or format, as long as you give appropriate credit to the original author(s) and the source, provide a link to the Creative Commons licence, and indicate if changes were made. The images or other third party material in this article are included in the article's Creative Commons licence, unless indicated otherwise in a credit line to the material. If material is not included in the article's Creative Commons licence and your intended use is not permitted by statutory regulation or exceeds the permitted use, you will need to obtain permission directly from the copyright holder. To view a copy of this licence, visit http://creativecommons.org/licen ses/by/4.0/.

\section{References}

Abdel-Motelib, A., Bode, M., Hartmann, R., Hartung, U., Hauptmann, A., \& Pfeiffer, K. (2012). Archaeometallurgical expeditions to the Sinai Peninsula and the Eastern Desert of Egypt (2006, 2008). Metalla, 19(1-2), 3-59.

Albers, G. (1996). Comparative aspects of regional cult structures of the Late Bronze and Early Iron Ages in the eastern Mediterranean (Aegean, Cyprus, Levant-Palestine). In E. De Miro, L. Godart, \& A. Sacconi (Eds.), Atti e Memorie, Secondo Congresso Internazionale di Micenologia. Incunabula Graeca (Vol. 98, No. 2, pp. 647-662). Gruppo Editoriale Internazionale.

Andreou, G. M. (2015). Traversing space: Landscape and identity in Bronze Age Cyprus (Doctoral Dissertation). University of Edinburgh, Edinburgh.

Andreou, G. M. (2016). Understanding the rural landscape of Late Bronze Age Cyprus: A diachronic perspective from the Vasilikos Valley. Journal of Mediterranean Archaeology, 29(2), 143-172.

Andreou, G. M. (2019). Socioeconomics of agrarian production: Considering rural cooperatives in the archaeology of the eastern Mediterranean through the lens of 2nd millennium BCE Cyprus. World Archaeology, 51, 291-310.

Antonaccio, C. (2016). Iron Age reciprocity. Journal of Mediterranean Archaeology, 29(1), 104-111.

Artzy, M. (1985). Supply and demand: A study of second millennium Cypriote pottery in the Levant. In A. B. Knapp \& T. Stech (Eds.), Prehistoric production and exchange: The Aegean and east 
Mediterranean. UCLA Institute of Archaeology, Monograph 25 (pp. 93-99). UCLA Institute of Archaeology.

Artzy, M. (2003). Bronze trade in the Late Bronze-Early Iron period: Tēl Māśōś and Tēl Kinrōt in the eastern Mediterranean context. In C. G. Den Hertog, U. Hübner, \& S. Münger (Eds.), Saxa loquentur: Studien zur archäologie Palästinas/Israels. Festschrift für Volkmar Fritz. Alter Orient und Altes Testament 300 (pp. 15-23). Ugarit-Verlag.

Artzy, M. (2006). The Jatt metal hoard in northern Canaanite/Phoenician and Cypriote context. Cuadernos de Arqueología Mediterránea 14. Edicions Bellaterra.

Aubet, M. E. (2001). The Phoenicians and the west: Politics, colonies and trade (2nd ed.). Cambridge University Press.

Bachhuber, C., \& Roberts, R. G. (2009). Forces of transformation: The end of the Bronze Age in the Mediterranean. Themes from the Ancient Near East, BANEA Publication Series 1. Oxbow.

Barton, C. M. (2014). Complexity, social complexity, and modeling. Journal of Archaeological Method and Theory, 21(2), 306-324.

Bass, G. F., Throckmorton, P., Taylor, J. D. P., Hennessy, J. B., Shulman, A. R., \& Buchholz, H.-G. (1967). Cape Gelidonya: A Bronze Age shipwreck. Transactions of the American Philosophical Society. New Series (Vol. 57, No. 8). American Philosophical Society.

Bell, C. (2006). The evolution of long-distance trading relationships across the LBA/Iron Age transition on the northern Levantine coast: Crisis, continuity and change. A study based on imported ceramics, bronze and its constituent metals. British Archaeological Reports: International Series 1574. Archaeopress.

Ben-Yosef, E. (2016). Back to Solomon's era: Results of the first excavations at 'Slaves' Hill' (Site 34, Timna, Israel). Bulletin of the American Schools of Oriental Research, 376, 169-198.

Ben-Yosef, E., Shaar, R., Tauxe, L., \& Ron, H. (2012). A new chronological framework for Iron Age copper production at Timna (Israel). Bulletin of the American Schools of Oriental Research, 367, 31-71.

Berger, D., Soles, J. S., Giumlia-Mair, A. R., Brügmann, G., Galili, E., Lockhoff, N., \& Pernicka, E. (2019). Isotope systematics and chemical composition of tin ingots from Mochlos (Crete) and other Late Bronze Age sites in the eastern Mediterranean Sea: An ultimate key to tin provenance? PLoS ONE, 14(6), e0218326. https://doi.org/10.1371/journal.pone.0218326

Bintliff, J. L. (Ed.). (1991). The Annales School and archaeology. Leicester University Press.

Bernabeu Aubán, J., Moreno Martin, A., \& Barton, C. M. (2012). Complex systems, social networks and the evolution of social complexity. In M. Berrocal, L. García Sanjuán, \& A. Gilman (Eds.), The prehistory of Iberia: Debating early social stratification and the state (pp. 23-37). Routledge.

Bradtmöller, M., Grimm, S., \& Riel-Salvatore, J. (2017a). Resilience theory in archaeological practiceAn annotated review. Quaternary International, 446, 3-16.

Bradtmöller, M., Riel-Salvatore, J., \& Grimm, S. B. (2017b). Adaptive cycles in archaeology. Quarternary International, 446, 1.

Bretschneider, J., Driessen, J., \& Kanta, A. (2021). Cyprus and Ugarit at the end of the Late Bronze Age: Insights from Pyla Kokkinokremos. In V. Matoïan (Ed.), Ougarit, un anniversaire. Bilans et recherches en cours. Ras Shamra-Ougarit 28 (pp. 607-638). Peeters.

Buckley, W. F. (1968). Society as a complex adaptive system. In W. F. Buckley (Ed.), Modern systems research for the behavioral scientist (pp. 490-513). Aldine Publishing Company.

Bürge, T., \& Fischer, P. M. (2019). Nuragic pottery from Hala Sultan Tekke: The Cypriot-Sardinian connection. Ägypten und Levante, 29, 231-244.

Cannavò, A. (2018). In the middle of the sea of the setting sun. In C. W. Tyson \& V. R. Herrmann (Eds.), Imperial peripheries in the Neo-Assyrian period (pp. 240-264). University Press of Colorado.

Catling, H. W. (1984). Workshop and heirloom: Prehistoric bronze stands in the east Mediterranean. Report of the Department of Antiquities Cyprus, pp. 69-91.

Catling, H. W. (1994). Cyprus in the 11th century BC-An end or a beginning? In V. Karageorghis (Ed.), Cyprus in the 11th century BC (pp. 133-142). Leventis Foundation.

Charalambous, A. (2016). A diachronic study of Cypriot copper alloy artefacts. Journal of Archaeological Science: Reports, 7, 566-573.

Cook, V. (1988). Cyprus and the outside world during the transition from the Bronze Age to the Iron Age. Opuscula Atheniensia, 17, 13-32.

Dikaios, P. (1967). Excavations and historical background: Enkomi in Cyprus. Journal of Historical Studies, Autumn, 1967, 41-49. 
Diakou, S. (2018). The upper Geometric cemetery at Lapithos: University of Pennsylvania Museum excavations 1931-1932. Studies in Mediterranean Archaeology 146. Astrom Editions.

Erb-Satullo, N. L. (2019). The innovation and adoption of iron in the ancient Near East. Journal of Archaeological Research, 27(4), 557-607.

Finkelstein, I., Langgut, M., Meiri, M., \& Sapir-Hen, L. (2017). Egyptian imperial economy in Canaan: Reaction to the climate crisis at the end of the Late Bronze Age. Ägypten und Levante, 27, 249-260.

Finné, M., Holmgren, K., Sundqvist, H. S., Weiberg, E., \& Lindblom, M. (2011). Climate in the eastern Mediterranean, and adjacent regions, during the past 6000 years-A review. Journal of Archaeological Science, 38(12), 3153-3173.

Finné, M., Woodbridge, J., Labuhn, I., \& Roberts, C. N. (2019). Holocene hydro-climatic variability in the Mediterranean: A synthetic multi-proxy reconstruction. The Holocene, 29(5), 847-863.

Fischer, P. M., \& Bürge, T. (2017). 'Sea Peoples' up-to-date: New research on transformations in the eastern Mediterranean in the 13th-11th centuries BCE. Österreichische Akademie der Wissenschaften, Denkschriften der Gesamtakademie 81. Verlag der Österreichischen Akademie der Wissenschaften.

Fischer, P. M., \& Bürge, T. M. (2018). Two Late Cypriot city quarters at Hala Sultan Tekke: The Söderberg Expedition 2010-2017. Studies in Mediterranean Archaeology 147. Astrom Editions.

Fourrier, S. (2013). Constructing the peripheries: Extra-urban sanctuaries and peer-polity interaction in Iron Age Cyprus. Bulletin of the American Schools of Oriental Research, 370, 103-122.

Furumark, A. (1965). The excavations at Sinda: Some historical results. Opuscula Atheniensia, 6, 99-116.

Gale, N. H., \& Stos-Gale, Z. A. (2012). The role of the Apliki mine region in the post c. 1400 BC copper production and trade networks in Cyprus and in the wider Mediterranean. In V. Kassianidou \& G. Papasavvas (Eds.), Eastern Mediterranean metallurgy and metalwork in the second millennium $B C$ : A conference in honour of James D. Muhly (pp. 70-82). Oxbow.

Galil, G., Gilboa, A., Maeir, A. M., \& Kahn, D. (Eds.). (2013). The ancient Near East in the 12th-10th centuries BCE: Culture and history. Alter Orient und Altes Testament 392. Ugarit-Verlag.

Galili, E., Gale, N., \& Rosen, B. (2013). A Late Bronze Age shipwreck with a metal cargo from Hishuley Carmel, Israel. International Journal of Nautical Archaeology, 42(1), 2-23.

Galili, E., Shmueli, N., \& Artzy, M. (1986). Bronze Age ship's cargo of copper and tin. International Journal Nautical Archaeology \& Underwater Exploration, 15(1), 25-37.

Genz, H. (2013). 'No land could stand before their arms, from Hatti... on...'? New light on the end of the Hittite empire and the early Iron Age in central Anatolia. In A. E. Killebrew \& G. Lehmann (Eds.), The Philistines and other 'Sea Peoples' in text and archaeology. Archaeology and Biblical Studies 15 (pp. 469-478). Society of Biblical Literature.

Georgiadou, A. (2012a). La production céramique de Kition au Chypro-Géométrique I. In M. Iacovou (Ed.), Cyprus and the Aegean in the early Iron Age: The legacy of Nicolas Coldstream (pp. 321344). Bank of Cyprus Cultural Foundation.

Georgiadou, A. (2012b). The early Cypro-Geometric I pottery: Examining the evidence from Lapithos Tomb 502. In A. Georgiou (Ed.), Cyprus, an island culture: Society and social relations from the Bronze Age to the Venetian period (pp. 85-103). Oxbow.

Georgiadou, A. (2018). La dimension régionale des échanges entre Chypre et le Levant à l'époque Chypro-géométrique ( $\mathrm{xi}^{\mathrm{e}}$-viii ${ }^{\mathrm{e}} \mathrm{s}$. av. J.-C.). In A. Cannavò \& L. Thély (Eds.), Les royaumes de Chypre à l'épreuve de l'histoire: Transitions et ruptures de la fin de l'âge du bronze au début de l'époque hellénistique. Suppléments du BCH 60 (pp. 49-65). École française d'Athènes.

Georgiou, A. (2011). The settlement histories of Cyprus at the opening of the twelfth century BC. Cahiers du Centre d'etudes Chypriotes, 41(1), 109-131.

Georgiou, A. (2012). Pyla-Kokkinokremos and Maa-Palaeokastro: A comparison of two naturally fortified Late Cypriot settlements. In A. Georgiou (Ed.), Cyprus-An island culture: Society and social relations from the Bronze Age to the Venetian period (pp. 65-83). Oxbow.

Georgiou, A. (2015). Cyprus during the 'Crisis Years' revisited. In A. Babbi, F. Bubenheimer-Erhart, B. Marín-Aguilera, \& S. Mühl (Eds.), The Mediterranean mirror: Cultural contacts in the Mediterranean Sea between 1200 and 750 BC. Tagungen 20 (pp. 129-145). Römisch-Germanisches Zentralmuseum.

Georgiou, A. (2017). Flourishing amidst a 'crisis': The regional history of the Paphos polity at the transition from the 13th to the 12th centuries BCE. In P. M. Fischer \& T. Bürge (Eds.), 'Sea Peoples' upto-date: New research on transformation in the eastern Mediterranean in the 13th-11th centuries 
BCE. Österreichische Akademie der Wissenschaften, Denkschriften der Gesamtakademie 81 (pp. 207-227). Verlag der Österreichischen Akademie der Wissenschaften.

Georgiou, A., \& Iacovou, M. (2020). Cyprus. In I. S. Lemos \& A. Kotsonas (Eds.), A companion to the archaeology of early Greece and the Mediterranean (pp. 1133-1162). Wiley-Blackwell.

Giddens, A. (1987). Social theory and modern sociology. Polity Press.

Gilboa, A. (2005). Sea Peoples and Phoenicians along the southern Phoenician coast-A reconciliation: An interpretation of Šikila (SKL) material culture. Bulletin of the American Schools of Oriental Research, 337, 47-78.

Gilboa, A., \& Goren, Y. (2015). Early Iron Age Phoenician networks: An optical mineralogy study of Phoenician Bichrome and related wares in Cyprus. Ancient West and East, 14, 73-110.

Gilboa, A., Waiman-Barak, P., \& Sharon, I. (2015). Dor, the Carmel coast and early Iron Age Mediterranean exchanges. In A. Babbi, F. Bubenheimer-Erhart, B. Marín-Aguilera, \& S. Mühl (Eds.), The Mediterranean mirror: Cultural contacts in the Mediterranean Sea between 1200 and 750 BC. Tagungen 20 (pp. 85-109). Römish-Germanischen Zentralmuseums.

Given, M., \& Knapp, A. B. (2003). The Sydney Cyprus Survey Project: Social approaches to regional archaeological survey. Monumenta Archaeologica 21. Cotsen Institute of Archaeology, UCLA.

Given, M., Knapp, A. B., Noller, J., Sollars, L., \& Kassianidou, V. (2013). Landscape and interaction: The Troodos Archaeological and Environmental Survey Project, Cyprus. Volume 1: Methodology, analysis and interpretation. Levant Supplementary Series 14. Council for British Research in the Levant.

Glatz, C., \& Matthews, R. (2005). Anthropology of a frontier zone: Hittite-Kaska relations in Late Bronze Age north-central Anatolia. Bulletin of the American Schools of Oriental Research, 339, 47-65.

Griggs, C., Pearson, C., Manning, S. W., \& Lorentzen, B. (2014). A 250-year annual precipitation reconstruction and drought assessment for Cyprus from Pinus brutia Ten. tree-rings. International Journal of Climatology, 34(8), 2702-2714.

Hadjisavvas, S. (2017). Alassa: Excavations at the Late Bronze Age sites of Pano Mandilares and Paliotaverna 1984-2000. Department of Antiquities, Cyprus.

Hankey, V. (1967). Mycenaean pottery in the Middle East: Notes on finds since 1951. Annual of the British School at Athens, 62, 107-147.

Hatzaki, E., \& Keswani, P. S. (2012). Mortuary practices and ideology in Bronze Age-Early Iron Age Crete and Cyprus: Comparative perspectives. In G. Cadogan, M. Iacovou, K. Kopaka, \& J. Whitley (Eds.), Parallel lives: Ancient island societies in Crete and Cyprus. British School at Athens, Studies 20 (pp. 307-330). British School at Athens.

Hirschfeld, N., \& Bass, G. F. (2013). Return to Cape Gelidonya. Pasiphae, 7, 99-104.

Iacovou, M. (1988). The pictorial pottery of eleventh century BC Cyprus. Studies in Mediterranean Archaeology 78. Paul Åströms Förlag.

Iacovou, M. (1999). Excerpta Cypria Geometrica: Materials for a history of Geometric Cyprus. In M. Iacovou \& D. Michaelides (Eds.), Cyprus: The historicity of the Geometric horizon (pp. 141-161). Archaeological Research Unit, University of Cyprus; Bank of Cyprus Cultural Foundation; Ministry of Education and Culture.

Iacovou, M. (2002). From ten to naught: Formation, consolidation and abolition of Cyprus' Iron Age polities. Cahiers du Centre d'études Chypriotes, 32(1), 73-87.

Iacovou, M. (2005a). Cyprus at the dawn of the first millennium BC: Cultural homogenisation versus the tyranny of ethnic identifications. In J. Clarke (Ed.), Archaeological perspectives on the transmission and transformation of culture in the eastern Mediterranean (pp. 125-134). Oxbow.

Iacovou, M. (2005b). The early Iron Age urban forms of Cyprus. In R. Osborne \& B. Cunliffe (Eds.), Mediterranean urbanization 800-600 BC. Proceedings of the British Academy 126 (pp. 17-43). Oxford University Press.

Iacovou, M. (2006). From the Mycenaean qa-si-re-u to the Cypriote pa-si-le-wo-se: The basileus in the kingdoms of Cyprus. In S. Deger-Jalkotzy \& I. S. Lemos (Eds.), Ancient Greece: From the Mycenaean palaces to the Age of Homer. Edinburgh Leventis Studies 3 (pp. 315-335). Edinburgh University Press.

Iacovou, M. (2007a). Advocating Cyprocentricism: An indigenous model for the emergence of state formation on Cyprus. In S. W. Crawford, A. Ben-Tor, J. P. Dessel, W. G. Dever, A. Mazar, \& J. Aviram (Eds.), 'Up to the gates of Ekron': Essays on the archaeology and history of the eastern 
Mediterranean in honor of Seymour Gitin (pp. 461-475). Albright Institute of Archaeological Research, Israel Exploration Society.

Iacovou, M. (2007b). Site size estimates and the diversity factor in Late Cypriot settlement histories. Bulletin of the American Schools of Oriental Research, 348, 1-23.

Iacovou, M. (2012). External and internal migrations during the 12th century BC: Setting the stage for an economically successful early Iron Age in Cyprus. In M. Iacovou (Ed.), Cyprus and the Aegean in the early Iron Age: The legacy of Nicolas Coldstream (pp. 207-227). Bank of Cyprus Cultural Foundation.

Iacovou, M. (2013). Historically elusive and internally fragile island polities: The intricacies of Cyprus's political geography in the Iron Age. Bulletin of the American Schools of Oriental Research, 370, $15-47$.

Iacovou, M. (2014). Political economies and landscape transformations: The case of ancient Paphos. In J. M. Webb (Ed.), Structure, measurement, and meaning: Studies on prehistoric Cyprus in honour of David Frankel. Studies in Mediterranean Archaeology 143 (pp. 161-174). Åströms Förlag.

Iacovou, M. (2018). From the Late Cypriot polities to the Iron Age 'kingdoms': Understanding the political landscape of Cyprus from within. In A. Cannavò \& L. Thély (Eds.), Les royaumes de Chypre à l'épreuve de l'histoire: Transitions et ruptures de la fin de l'âge du bronze au début de l'époque hellénistique. Suppléments du BCH 60 (pp. 7-28). École française d'Athènes.

Janes, S. (2008). The Cypro-Geometric horizon, a view from below: Identity and social change in the mortuary record (Doctoral Dissertation). Department of Archaeology, University of Glasgow, Glasgow.

Janes, S. (2013). Death and burial in the age of the Cypriot city-kingdoms: Social complexity based on the mortuary evidence. Bulletin of the American Schools of Oriental Research, 370, 145-168.

Janeway, B. (2017). Sea Peoples in the northern Levant? Aegean-style pottery from early Iron Age Tell Tayinat. Studies in the Archaeology and History of the Levant 7. Eisenbrauns.

Joffe, A. H. (2002). The rise of secondary states in the Iron Age Levant. Journal of the Economic and Social History of the Orient, 45, 425-467.

Kaniewski, D., Marriner, N., Bretschneider, J., Jans, G., Morhange, C., Cheddadi, R., et al. (2019). 300year drought frames Late Bronze Age to early Iron Age transition in the Near East: New palaeoecological data from Cyprus and Syria. Regional Environmental Change, 19(8), 2287-2297.

Kaniewski, D., \& Van Campo, E. (2017). The climatic context of the $3.2 \mathrm{kyr}$ cal BP Event. In P. M. Fischer \& T. Bürge (Eds.), 'Sea Peoples' up-to-date: New research on transformation in the eastern Mediterranean in the 13th-11th Centuries BCE. Österreichische Akademie der Wissenschaften, Denkschriften der Gesamtakademie 81 (pp. 85-94). Verlag der Österreichischen Akademie der Wissenschaften.

Kaniewski, D., Van Campo, E., Guiot, J., Le Burel, S., Otto, T., \& Baeteman, C. (2013). Environmental roots of the Late Bronze Age crisis. PLoS ONE, 8(8), e71004. https://doi.org/10.1371/journal.pone. 0071004

Karageorghis, V., \& Demas, M. (1984). Pyla-Kokkinokremos: A late 13th Century BC fortified settlement in Cyprus. Department of Antiquities, Cyprus.

Karageorghis, V., \& Demas, M. (1988). Excavations at Maa-Palaeokastro 1979-1986. Department of Antiquities, Cyprus.

Karageorghis, V., \& Kassianidou, V. (1999). Metalworking and recycling in Late Bronze Age CyprusThe evidence from Kition. Oxford Journal of Archaeology, 18(2), 171-188.

Karageorghis, V., \& Papasavvas, G. (2001). A bronze ingot-bearer from Cyprus. Oxford Journal of Archaeology, 20(4), 339-354.

Karageorghis, V., \& Raptou, E. (2014). Necropoleis at Palaepaphos from the end of the Late Bronze Age to the Cypro-Archaic period. The Cyprus Institute.

Karageorghis, V., \& Raptou, E. (2016). Palaepaphos-Skales: Tombs of the Late Cypriote IIIB and CyproGeometric periods (Excavations of 2008 and 2011). The Cyprus Institute.

Karageorghis, V., \& Raptou, E. (2019). Palaepaphos-Skales Tomb 277. More prestigious burials. Opuscula, 12, 327-367.

Kassianidou, V. (2003). The trade of tin and the island of copper. In A. Giumlia-Mair \& F. Lo Schiavo (Eds.), The problem of early tin. British Archaeological Reports, International Series 1199 (pp. 109-119). Archaeopress.

Kassianidou, V. (2004). 'And at Tamassos there are important mines of copper' (Strabo, Geography 14.6.5). Cahier du Centre d'études Chypriotes, 34, 33-46. 
Kassianidou, V. (2012). The origin and use of metals in Iron Age Cyprus. In M. Iacovou (Ed.), Cyprus and the Aegean in the early Iron Age: The legacy of Nicolas Coldstream (pp. 229-259). Bank of Cyprus Cultural Foundation.

Kassianidou, V. (2013). The exploitation of the landscape: Metal resources and the copper trade during the age of the Cypriot city-kingdoms. Bulletin of the American Schools of Oriental Research, 370, 49-82.

Kassianidou, V. (2014). Cypriot copper for the Iron Age world of the eastern Mediterranean. In J. M. Webb (Ed.), Structure, measurement and meaning: Studies on prehistoric Cyprus in honor of David Frankel. Studies in Mediterranean Archaeology 143 (pp. 261-271). Aströms Förlag.

Kearns, C. (2015). Unruly landscapes: The making of 1st millennium BCE polities on Cyprus (Doctoral Dissertation). Cornell University.

Kearns, C. (2017). Mediterranean archeology and environmental histories in the spotlight of the Anthropocene. History Compass, 15(10), e12371. https://doi.org/10.1111/hic3.12371

Kearns, C. (2019). Discerning 'favorable' environments: Science, survey archaeology and the Cypriot Iron Age. In C. Kearns \& S. W. Manning (Eds.), New directions in Cypriot archaeology (pp. 266294). Cornell University Press.

Keswani, P. S. (1989). Dimensions of social hierarchy in Late Bronze Age Cyprus: An analysis of the mortuary data from Enkomi. Journal of Mediterranean Archaeology, 2(1), 49-86.

Keswani, P. S. (1993). Models of local exchange in Late Bronze Age Cyprus. Bulletin of the American Schools of Oriental Research, 292, 73-83.

Keswani, P. S. (1997). Hierarchies, heterarchies, and urbanization processes: The view from Bronze Age Cyprus. Journal of Mediterranean Archaeology, 9(2), 211-250.

Keswani, P. S. (2004). Mortuary ritual and society in Bronze Age Cyprus. Monographs in Mediterranean Archaeology 4. London: Equinox.

Kiderlen, M., Bode, M., Hauptmann, A., \& Bassiakos, Y. (2016). Tripod cauldrons produced at Olympia give evidence for trade with copper from Faynan (Jordan) to southwest Greece, c. 950-750 BCE. Journal of Archaeological Science: Reports, 8, 303-313.

Knapp, A. B. (Ed.). (1992a). Archaeology, annales, and ethnohistory. Cambridge University Press.

Knapp, A. B. (1992b). Archaeology and Annales: Time, space, and change. In A. B. Knapp (Ed.), Archaeology, annales, and ethnohistory (pp. 1-21). Cambridge University Press.

Knapp, A. B. (1996). Near Eastern and Aegean texts from the third to the first millennia BC. In P. W. Wallace \& A. G. Orphanides (Eds.), Sources for the history of Cyprus II. Cyprus Research Center.

Knapp, A. B. (1997). The archaeology of Late Bronze Age Cypriot society: The study of settlement, survey and landscape. Department of Archaeology, University of Glasgow, Occasional Paper 4. Glasgow: Department of Archaeology, University of Glasgow.

Knapp, A. B. (2003). The archaeology of community on Bronze Age Cyprus: Politiko Phorades in context. American Journal of Archaeology, 107, 559-580.

Knapp, A. B. (2008). Prehistoric and protohistoric Cyprus: Identity, insularity, and connectivity. Oxford University Press.

Knapp, A. B. (2013). The archaeology of Cyprus: From earliest prehistory through the Bronze Age. Cambridge University Press.

Knapp, A. B. (2018a). Seafaring and seafarers in the Bronze Age eastern Mediterranean. Sidestone Press.

Knapp, A. B. (2018b). Wealth, inequality and complexity: Mortuary practices at Kalavasos Ayios Dhimitrios. In L. Hulin, L. Crewe, \& J. M. Webb (Eds.), Structures of inequality on Bronze Age Cyprus: Studies in honour of Alison K. South. Studies in Mediterranean Archaeology PB 187 (pp. 7-19). Astrom Editions.

Knapp, A. B., \& Manning, S. W. (2016). Crisis in context: The end of the Late Bronze Age in the eastern Mediterranean. American Journal of Archaeology, $120(1), 99$.

Knapp, A. B., \& Meyer, N. (2020). Cyprus: Bronze Age demise, Iron Age regeneration. In G. D. Middleton (Ed.), Collapse and transformation: The Late Bronze Age to early Iron Age in the Aegean (pp. 237-246). Oxbow.

Knappett, C. (2009). Scaling up: From household to state in Bronze Age Crete. In S. Owen \& L. Preston (Eds.), Inside the city in the Greek world: Studies of urbanism from the Bronze Age to the Hellenistic period. University of Cambridge Museum of Classical Archaeology Monograph 1 (pp. 14-26). Oxbow.

Kohler, T. A. (2012). Complex systems and archaeology. In I. Hodder (Ed.), Archaeological theory today (pp. 93-123). Polity Press. 
Körner, C. (2016). The Cypriot kings under Assyrian and Persian rule (eighth to fourth century BC): Centre and periphery in a relationship of suzerainty. Electrum, 23, 25-49.

Kristiansen, K., \& Earle, T. (2015). Neolithic versus Bronze Age social formations: A political economy approach. In K. Kristiansen, L. Šmejda, \& J. Turek (Eds.), Paradigm found: Archaeological theory present, past and future. Essays in honour of Evžen Neustupný (pp. 234-247). Oxbow.

Langgut, M., Finkelstein, I., \& Litt, T. (2013). Climate and the Late Bronze collapse: New evidence from the southern Levant. Tel Aviv, 40, 149-175.

Lansing, J. S. (2003). Complex adaptive systems. Annual Review of Anthropology, 32(1), 183-204.

Lansing, J. S. (2015). Complexity: An emerging trend in social sciences. In R. A. Scott \& S. M. Kosslyn (Eds.), Emerging trends in the social and behavioral sciences. Wiley Online Library. https://doi. org/10.1002/9781118900772.etrds0048

Lehmann, G. (2017). The Late Bronze-Iron Age transition and the problem of the Sea Peoples phenomenon in Cilicia. In P. M. Fischer \& T. Bürge (Eds.), 'Sea Peoples' up-to-date: New research on transformations in the eastern Mediterranean in the 13th-11th centuries BCE. Österreichische Akademie der Wissenschaften, Denkschriften der Gesamtakademie 81 (pp. 229-256). Verlag der Österreichischen Akademie der Wissenschaften.

Lehner, M. (2000). Fractal house of pharaoh: Ancient Egypt as a complex adaptive system, a trial. In T. A. Kohler \& G. J. Gumerman (Eds.), Dynamics in human and primate societies: Agent-based modeling of social and spatial processes (pp. 275-353). Oxford University Press.

Levy, T. E., Ben-Yosef, E., \& Najjar, M. (2012). New perspectives on Iron Age copper production and society in Faynan region, Jordan. In V. Kassianidou \& G. Papasavvas (Eds.), Eastern Mediterranean metallurgy and metalwork in the second millennium BC: A conference in honour of James D. Muhly (pp. 197-214). Oxbow.

Levy, T. E., Ben-Yosef, E., \& Najjar, M. (2018). Intensive surveys, large-scale excavation strategies and Iron Age industrial metallurgy in Faynan, Jordan: Fairy tales don't come true. In E. Ben-Yosef (Ed.), Mining for ancient copper: Essays in memory of Beno Rothenberg. Sonia And Marco Nadler Institute of Archaeology Monograph Series 37 (pp. 245-258). Nadler Institute of Archaeology, TelAviv University.

Liss, B., Howland, M. D., Lorentzen, B., Smitheram, C., Najjar, M., \& Levy, T. E. (2020). Up the wadi: Development of an Iron Age industrial landscape in Faynan, Jordan. Journal of Field Archaeology. https://doi.org/10.1080/00934690.2020.1747792

Manning, S. W. (1998). Changing pasts and socio-political cognition in Late Bronze Age Cyprus. World Archaeology, 30(1), 39-58.

Manning, S. W., Andreou, G.-M., Fisher, K. D., Gerard-Little, P., Kearns, C., Leon, J. F., et al. (2014). Becoming urban: Investigating the anatomy of the Late Bronze Age complex, Maroni Cyprus. Journal of Mediterranean Archaeology, 27(1), 3-32.

Manning, S. W., Kearns, C., \& Lorentzen, B. (2017). Dating the end of the Late Bronze Age with radiocarbon: Some observations, concerns, and revisiting the dating of the Late Cypriot IIC to IIIA. In P. M. Fischer \& T. Bürge (Eds.), 'Sea Peoples' up-to-date: New research on transformation in the eastern Mediterranean in 13th-11th centuries BCE. Österreichische Akademie der Wissenschaften, Denkschriften der Gesamtakademie 81 (pp. 95-110). Verlag der Österreichischen Akademie der Wissenschaften.

Markoe, G. (2000). The Phoenicians. British Museum Press.

Marsh, E. J. (2016). The disappearing desert and the emergence of agropastoralism: An adaptive cycle of rapid change in the mid-Holocene Lake Titicaca Basin (Peru-Bolivia). Quaternary International, $422,123-134$.

McAnany, P. A., \& Yoffee, N. (2010). Questioning collapse: Human resilience, ecological vulnerability, and the aftermath of empire. Cambridge University Press.

McGeough, K. M. (2007). Exchange relationships at Ugarit. Ancient Near Eastern Studies 26. Peeters.

Merrillees, R. S. (1968). The Cypriote Bronze Age pottery found in Egypt. Studies in Mediterranean Archaeology 18. P. Åström's Förlag.

Middleton, G. D. (2017). Understanding collapse: Ancient history and modern myths. Cambridge University Press.

Middleton, G. D. (Ed.). (2020). Collapse and transformation: The Late Bronze Age to early Iron Age in the Aegean. Oxbow.

Millek, J. M. (2019). Exchange, destruction, and a transitioning society: Interregional exchange in the southern Levant from the Late Bronze Age to the Iron I. Ressourcen Kulturen 9. Tübingen University Press. 
Monroe, C. M. (2010). Sunk costs at Late Bronze Age Uluburun. Bulletin of the American Schools of Oriental Research, 357, 19-33.

Monroe, C. M. (2018). Marginalizing civilization: the Phoenician redefinition of power ca. 1300-800 BCE. In K. Kristiansen, T. Lindkvist, \& J. Myrdal (Eds.), Trade and civilisation: Economic networks and cultural ties, from prehistory to the early Modern Era (pp. 195-241). Cambridge University Press.

Mountjoy, P. A., \& Mommsen, H. (2015). Neutron activation analysis of Aegean-style IIIC pottery from 11 Cypriot and various Near Eastern sites. Ägypten und Levante, 25, 421-508.

Mountjoy, P. A., \& Mommsen, H. (2019). Neutron activation analysis of Aegean-style IIIC pottery from Maa: Palaeokastro, Cyprus, and a discussion of the foundation of the site. Ägypten und Levante, 29, 273-301.

Muhly, J. D. (2003). Greece and Anatolia in the early Iron Age: The archaeological evidence and the literary tradition. In W. G. Dever \& S. Gitin (Eds.), Symbiosis, symbolism, and the power of the past: Canaan, ancient Israel, and their neighbors, from the Late Bronze Age through Roman Palaestina (pp. 23-35). Eisenbrauns.

Muhly, J. D., \& Kassianidou, V. (2012). Parallels and diversities in the production, trade and use of copper and iron in Crete and Cyprus from the Bronze Age to the Iron Age. In G. Cadogan, M. Iacovou, K. Kopaka, \& J. Whitley (Eds.), Parallel lives: ancient island societies in Crete and Cyprus. British School at Athens, Studies 20 (pp. 119-140). British School at Athens.

Murray, S. C. (2017). The collapse of the Mycenaean economy: Imports, trade, and institutions 1300-700 $B C E$. Cambridge University Press.

Murray, S. C. (2020). The changing economy. In G. Middleton (Ed.), Collapse and transformation: The Late Bronze Age to early Iron Age in the Aegean (pp. 201-208). Oxbow.

Nakassis, D. (2013). Individuals and society in Mycenaean Pylos. Mnemosyne Supplement 358. Brill.

Negbi, O. (2005). Urbanism on Late Bronze Age Cyprus: LC II in retrospect. Bulletin of the American Schools of Oriental Research, 337, 1-45.

Osborne, J. (2013). Sovereignty and territoriality in the city-state: A case study from the Amuq Valley, Turkey. Journal of Anthropological Archaeology, 32, 774-790.

Palermo, J. (2018). The impact of iron technology on the economy of the Aegean and Cyprus from 1200850 BCE (Doctoral Dissertation). University College, University of Oxford.

Papantoniou, G. (2012a). Religion and social transformations in Cyprus: From the Cypriot basileis to the Hellenistic strategos. Mnemosyne Supplement 347. Brill.

Papantoniou, G. (2012b). Cypriot sanctuaries and religion in the early Iron Age: Views from before and after. In M. Iacovou (Ed.), Cyprus and the Aegean in the early Iron Age. The legacy of Nicolas Coldstream (pp. 285-319). Bank of Cyprus Cultural Foundation.

Papantoniou, G. (2016). Cypriot ritual and cult from the Bronze to the Iron Age: A longue-durée approach. Journal of Greek Archaeology, 1, 73-108.

Papantoniou, G., \& Bourogiannis, G. (2018). The Cypriot extra-urban sanctuary as a central place: The case of Agia Irini. In G. Papantoniou \& A. Vionis (Eds.), Central places and un-central landscapes: Political economies and natural resources in the longue durée. Land Special Issue 7(139) (pp. 133-160). MDPI.

Papantoniou, G., \& Kyriakou, N. (2018). Sacred landscapes and the territoriality of Iron Age Cypriot polities: The applicability of GIS. American Journal of Archaeology, 122(4), 541-577.

Papantoniou, G., \& Vionis, A. (2018). The river as an economic asset: Settlement and society in the Xeros Valley in Cyprus. In G. Papantoniou \& A. Vionis (Eds.), Central places and un-central landscapes: Political economies and natural resources in the longue durée. Land Special Issue 7(157) (pp. 40-69). MDPI.

Papantoniou, G., \& Vionis, A. (Eds.). (2019). Central places and un-central landscapes: Political economies and natural resources in the longue durée. Land Special Issue 7. MDPI.

Papasavvas, G. (2004). Cypriot bronze stands and their Mediterranean perspective. Revista d'arqueologia de Ponent, 14, 31-59.

Papasavvas, G. (2012). Profusion of Cypriot copper abroad and dearth of bronzes at home: Reflections on a paradox in Late Bronze Age Cyprus. In V. Kassianidou \& G. Papasavvas (Eds.), Eastern Mediterranean metallurgy and metalwork in the second millennium BC: A conference in honour of James D. Muhly (pp. 117-128). Oxbow.

Papasavvas, G. (2021). What could a copper oxhide ingot 'buy' in the markets of the Late Bronze Age eastern Mediterranean? In M. Perra \& F. Lo Schiavo (Eds.), Cultural contacts and trade in Nuragic Sardinia: The southern route (Sardinia, Sicily, Crete and Cyprus) (pp. 127-150). Arkadia Editore. 
Papasavvas, G., \& Kassianidou, V. (2015). The new status of copper and bronze on Cyprus at the end of the Late Bronze Age. In C. F. Macdonald, E. Hatzaki, \& S. Andreou (Eds.), The great islands: Studies of Crete and Cyprus presented to Gerald Cadogan (pp. 230-236). Kapon Editions.

Peltenburg, E. (1996). From isolation to state formation in Cyprus, c. 3500-1500 BC. In V. Karageorghis $\&$ D. Michaelides (Eds.), The development of the Cypriot economy: From the prehistoric period to the present day (pp. 17-44). Bank of Cyprus, University of Cyprus.

Peltenburg, E. (2012). Text meets material in Late Bronze Age Cyprus. In A. Georgiou (Ed.), Cyprus, an island culture: Society and social relations from the Bronze Age to the Venetian period (pp. 1-23). Oxbow.

Peltenburg, E., \& Iacovou, M. (2012). Crete and Cyprus: Contrasting political configurations. In G. Cadogan, M. Iacovou, K. Kopaka, \& J. Whitley (Eds.), Parallel lives: Ancient island societies in Crete and Cyprus. British School at Athens, Studies 20 (pp. 345-363). British School at Athens.

Petit, T. (2001). The first palace of Amathus and the Cypriot poleogenesis. In I. Nielsen (Ed.), The royal palace institution in the first millennium BC: Regional development and cultural interchange between east and west. Monographs of the Danish Institute at Athens 4 (pp. 53-75). Danish Institute at Athens.

Petit, T. (2015). La ville et le royaume d'Amathonte n'ont pas été fondés au XIe siècle. In D. Lefèvre Novaro, L. Martzolff, \& M. Ghilardi (Eds.), Géosciences, archéologie et histoire en Crète de l'âge du bronze récent à l'époque archaïque (pp. 353-375). Aldo Ausilio Editore e Bottega d'Erasmo.

Petit, T. (2019). La naissance des cités-royaumes cypriotes. Archaeopress. https://doi.org/10.2307/j. ctvwh8bz6

Pickles, S. (1988). Metallurgical changes in Late Bronze Age Cyprus. Occasional Paper 17. University of Edinburgh, Department of Archaeology.

Pickles, S., \& Peltenburg, E. (1998). Metallurgy, society and the Bronze/Iron transition in the east Mediterranean and the Near East. Report of the Department of Antiquities, Cyprus, pp. 67-100.

Porter, B. W. (2013). Complex communities: The archaeology of early Iron Age west-central Jordan. University of Arizona Press.

Porter, B. W. (2016). Assembling the Iron Age Levant: The archaeology of communities, polities, and imperial peripheries. Journal of Archaeological Research, 24(4), 373-420.

Pulak, C. (2000). The copper and tin ingots from the Late Bronze Age shipwreck at Uluburn. In Ü. Yalçın (Ed.), Anatolian metal I. Der Anschnitt, Beiheft 13 (pp. 137-157). Deutsches Bergbau-Museum.

Pulak, C. (2009). The Uluburun tin ingots and the shipment of tin by sea in the Late Bronze Age Mediterranean. Tübaar, 12, 189-207.

Rademakers, F. W., Rehren, T., \& Pernicka, E. (2017). Copper for the Pharaoh: Identifying multiple metal sources for Ramesses' workshops from bronze and crucible remains. Journal of Archaeological Science, 80, 50-73.

Renfrew, C., \& Cherry, J. F. (1986). Peer polity interaction and socio-political change. Cambridge University Press.

Reyes, A. T. (1994). Archaic Cyprus: A study of the textual and archaeological evidence. Clarendon Press.

Reyes, A. T. (2002). The stamp seals of Cyprus in the Late Bronze Age and the Iron Age: An introduction. In J. S. Smith (Ed.), Script and seal use on Cyprus in the Bronze and Iron Ages AIA. Colloquia and Conference Papers 4 (pp. 213-226). Archaeological Institute of America.

Routledge, B. (2017). Is there an Iron Age Levant? Revista del Instituto de Historia Antigua Oriental, 18, 49-76.

Rupp, D. W. (1987). Vive le roi: The emergence of the state in Iron Age Cyprus. In D. Rupp (Ed.), Western Cyprus: Connections. Studies in Mediterranean Archaeology 77 (pp. 147-168). P. Åström's Förlag.

Rupp, D. W. (1988). The 'royal tombs' at Salamis (Cyprus): Ideological messages of power and authority. Journal of Mediterranean Archaeology, 1(1), 111-139.

Rupp, D. W. (1989). Puttin' on the Ritz: Manifestations of high status in Iron Age Cyprus. In E. Peltenburg (Ed.), Early society in Cyprus (pp. 336-362). Edinburgh University Press.

Rupp, D. W. (1998). The seven kings of the land of Ia', a district on Ia-ad-na-na: Achaean bluebloods, Cypriot parvenus or both? In K. J. Hartswick \& M. Sturgeon (Eds.), Stefanoß: Studies in Honor of Brunilde Sismondo Ridgway (pp. 209-222). University Museum, University of Pennsylvania.

Satraki, A. (2012). Cypriot polities in the early Iron Age. In M. Iacovou (Ed.), Cyprus and the Aegean in the early Iron Age: The legacy of Nicolas Coldstream (pp. 261-283). Bank of Cyprus Cultural Foundation. 
Schwartz, G. M., \& Nichols, J. J. (Eds.). (2006). After collapse: The regeneration of complex societies. University of Arizona Press.

Sherratt, A., \& Sherratt, S. (1991). From luxuries to commodities: The nature of Mediterranean Bronze Age trading systems. In N. H. Gale (Ed.), Bronze Age trade in the Mediterranean. Studies in Mediterranean Archaeology 90 (pp. 351-386). Paul Åströms Förlag.

Sherratt, S. (1991). Cypriot pottery of Aegean type in LC II-III: Problems of classification, chronology and interpretation. Cypriot ceramics: Reading the prehistoric record. University Museum Monograph 74 (pp. 185-196). University of Pennsylvania.

Sherratt, E. S. (1992). Immigration and archaeology: Some indirect reflections. In P. Åström (Ed.), Acta Cypria 2. Studies in Mediterranean Archaeology and Literature, Pocketbook 117 (pp. 316-347). Paul Åströms Förlag.

Sherratt, S. (1994a). Commerce, iron and ideology: Metallurgical innovation in 12th-11th century Cyprus. In V. Karageorghis (Ed.), Cyprus in the 11th Century BC (pp. 59-106). A. G. Leventis Foundation, University of Cyprus.

Sherratt, E. S. (1994b). Patterns of contact between the Aegean and Cyprus in the 13th and 12th centuries BC. Archaeologia Cypria, 3, 35-46.

Sherratt, S. (1998). 'Sea Peoples' and the economic structure of the late second millennium in the Eastern Mediterranean. In S. Gitin, A. Mazar, \& E. Stern (Eds.), Mediterranean peoples in transition: Thirteenth to early tenth centuries BCE (pp. 292-313). Israel Exploration Society.

Sherratt, S. (1999). E pur si muove: Pots, markets and values in the second millennium Mediterranean. In J. P. Crielaard, V. Stissi, \& G. J. van Wijngaarden (Eds.), The complex past of pottery: Production, circulation and consumption of Mycenaean and Greek pottery (sixteenth to early fifth centuries $B C)$ (pp. 163-211). J. C. Gieben.

Sherratt, S. (2003). The Mediterranean economy: 'Globalization'at the end of the second millennium BCE. In W. G. Dever \& S. Gitin (Eds.), Symbiosis, symbolism, and the power of the past: Canaan, ancient Israel, and their neighbors from the Late Bronze Age through Roman Palaestina (pp. 37-62). Eisenbrauns.

Sherratt, S. (2016a). From 'institutional' to 'private': Traders, routes and commerce from the Late Bronze Age to the Iron Age. In J. C. Moreno Garcia (Ed.), Dynamics of production in the ancient Near East, 1300-500 BC (pp. 289-301). Oxbow.

Sherratt, S. (2016b). A globalizing Bronze and Iron Age Mediterranean. In T. Hodos, A. Geurds, P. Lane, I. Lilley, M. Pitts, \& G. Shelach (Eds.), The Routledge handbook of archaeology and globalization (pp. 602-617). Routledge.

Smith, J. S. (2008). Cyprus, the Phoenicians and Kition. In C. Sagona (Ed.), Beyond the homeland: Markers in Phoenician chronology. Ancient Near Eastern Studies 28 (pp. 261-303). Peeters.

Smith, J. S. (2009). Art and society in Cyprus from the Bronze Age into the Iron Age. Cambridge University Press.

Smith, J. S. (2018). The changing urban landscape of Marion. In A. Cannavò \& L. Thély (Eds.), Les royaumes de Chypre à l'épreuve de l'histoire: Transitions et ruptures de la fin de l'âge du bronze au début de l'époque hellénistique. Suppléments du BCH 60 (pp. 167-186). École française d'Athènes.

Snodgrass, A. M. (1988). Cyprus and early Greek history. Bank of Cyprus, Cultural Foundation, 4th Annual Lecture. Bank of Cyprus Cultural Foundation.

South-Todd, A. (2002). Late Bronze Age settlement patterns in southern Cyprus: The first kingdoms? Cahiers du Centre d'études Chypriotes, 32, 59-72.

Steel, L. (1993a). Burial customs in Cyprus at the transition from the Bronze Age to the Iron Age (Doctoral Dissertation). University College London.

Steel, L. (1993b). The establishment of the city kingdoms in Iron Age Cyprus: An archaeological commentary. The Report of the Department of Antiquities Cyprus, pp. 147-156.

Steel, L. (1994). Pottery production in Cyprus in the eleventh century BC. In V. Karageorghis (Ed.), Cyprus in the 11th century BC (pp. 239-246). A.G. Leventis Foundation.

Steel, L. (1998). The social impact of Mycenaean imported pottery in Cyprus. The Annual of the British School at Athens, 93, 285-296.

Steel, L. (2004). A reappraisal of the distribution, context and function of Mycenaean pottery in Cyprus. In La céramique Mycénienne de l'Égée au Levant. Travaux de la Maison de l'Orient et de la Méditerranée 41 (pp. 69-85). Maison de l'Orient et de la Méditerranée Jean Pouilloux. 
Stöllner, T., Samaschev, Z., Berdenov, S., Cierny, J., Doll, M., Garner, J., et al. (2011). Tin from Kazakhstan: Steppe tin for the West. In Ü. Yalçın (Ed.), Anatolian metal V. Der Anschnitt, Beiheft 24 (pp. 231-252). Deutsches Bergbau-Museum.

Swantek, L. A. (2017). A change is going to come: A complex systems approach to the emergence of social complexity on Cyprus (Doctoral Dissertation). Department of Anthropology, Arizona State University.

Swiny, S. (2004). The rôle of intuitive and small-scale surveys in landscape archaeology. In M. Iacovou (Ed.), Archaeological field survey in Cyprus: Past history, future potentials. British School at Athens Studies 11 (pp. 55-61). The British School at Athens.

Symons, S., \& Raine, D. (2009). Agent-based models of ancient Egypt. In N. Strudwick (Ed.), Information technology and Egyptology in 2008 (pp. 129-146). Gorgias Press.

Tainter, J. A. (1988). The collapse of complex societies. Cambridge University Press.

Todd, I. A. (2013). The field survey of the Vasilikos Valley 3: Human settlement in the Vasilikos Valley Studies in Mediterranean Archaeology (Vol. 7, No. 12). P. Åström's Förlag.

van Wijngaarden, G. J. (2002). Use and appreciation of Mycenaean pottery in the Levant, Cyprus and Italy. Amsterdam University Press.

Vanschoonwinkel, J. (1994). La présence grecque à Chypre au XIe siècle av. J.-C. In V. Karageorghis (Ed.), Cyprus in the 11th Century BC (pp. 109-132). Nicosia: Leventis Foundation.

Voskos, I., \& Knapp, A. B. (2008). Cyprus at the end of the Late Bronze Age: Crisis and colonization or continuity and hybridization? American Journal of Archaeology, 112(4), 659-684.

Waldbaum, J. C. (1978). From bronze to iron: The transition from the Bronze Age to the Iron Age in the eastern Mediterranean. Studies in Mediterranean Archaeology 54. Paul Åströms Förlag.

Waldbaum, J. C. (1999). The coming of iron in the eastern Mediterranean: Thirty years of archaeological and technological research. In V. C. Pigott (Ed.), The archaeometallurgy of the Asian old world (pp. 27-57). The University Museum, University of Pennsylvania.

Webb, J. M. (1999). Ritual architecture, iconography and practice in the Late Cypriote Bronze Age. Studies in Mediterranean Archaeology and Literature, Pocketbook 75. P. Åström's Förlag.

Webb, J. M. (2018). Spatial and social discontinuities in burial practice and the privatisation of mortuary space in Bronze Age Cyprus. Journal of Mediterranean Archaeology, 31(2), 203-228.

Webb, J. M., \& Weingarten, J. (2012). Seals and seal use: Markers of social, political and economic transformations on two islands. In G. Cadogan, M. Iacovou, K. Kopaka, \& J. Whitley (Eds.), Parallel lives: Ancient island societies in Crete and Cyprus. British School at Athens Studies 20 (pp. 85-104). British School at Athens.

Yagel, O. A., Ben-Yosef, E., \& Craddock, P. T. (2016). Late Bronze Age copper production in Timna: New evidence from Site 3. Levant, 48, 33-51.

Yahalom-Mack, N. (2017). Metal production and trade at the turn of the first millennium BCE: Some answers, new questions. In O. Lipschits, Y. Gadot, \& M. J. Adams (Eds.), Rethinking Israel: Studies in the history and archaeology of ancient Israel in honor of Israel Finkelstein (pp. 451-461). Eisenbrauns.

Yahalom-Mack, N., Galili, E., Segal, I., Eliyahu-Behar, A., Boaretto, E., Shilstein, S., \& Finkelstein, I. (2014). New insights into Levantine copper trade: Analysis of ingots from the Bronze and Iron Ages in Israel. Journal of Archaeological Science, 45, 159-177.

Yahalom-Mack, N., \& Segal, I. (2018). The origin of the copper used in Canaan during the Late Bronze/ Iron Age transition. In E. Ben-Yosef (Ed.), Mining for ancient copper. Essays in memory of Beno Rothenberg. Sonia \& Marco Nadler Institute of Archaeology Monograph Series 37 (pp. 313-331). Nadler Institute of Archaeology, Tel-Aviv University.

Yasur-Landau, A., Ebeling, J. R., \& Mazow, L. B. (Eds.). (2011). Household archaeology in ancient Israel and beyond. Brill.

Yoffee, N., \& Cowgill, G. L. (Eds.). (1988). The collapse of ancient states and civilisations. University of Arizona Press.

Zaccagnini, C. (1990). The transition from bronze to iron in the Near East and in the Levant: Marginal notes. Journal of the American Oriental Society, 110(3), 493-502.

Zukerman, A. (2012). Bronze wheeled stands in a new Ugaritic text. Revue Biblique, 119(4), 481-497.

Publisher's Note Springer Nature remains neutral with regard to jurisdictional claims in published maps and institutional affiliations. 